\title{
MAKING SENSE OF NONSENSE: Intellectual Property, ANTITRUst, AND MARKET POWER
}

\begin{abstract}
Ariel Katz
While the economic rationale for intellectual property ("IP") rights rests on the concepts of "monopoly" or "market power," the Supreme Court, in Illinois Tool Works v. Independent Ink, has recently joined a "virtual consensus" among antitrust commentators believing that no presumption of market power should exist in antitrust cases involving IP. This Article critically analyzes this consensus, and clarifies the relationship between IP and market power, shows why IP rights often do confer market power in the antitrust sense, but also explains why acknowledging this should not necessarily lead to oversized application of antitrust law to IP.
\end{abstract}

Introduction.

Part I. A Concise History of the Presumption of Market Power in the

Antitrust-Intellectual Property Context.

A. The Early Years

B. The Nine No-No's.

C. Building a "Virtual Consensus": From Presumption to Anti-

Presumption. 846

Part II. The Denialists' Puzzle .....

Part III. The Attempts to Resolve the Puzzle

A. "Market Power in the Antitrust Sense". 853

* Assistant Professor and Innovation Chair in Electronic Commerce, Faculty of Law, University of Toronto. I wish to thank Abraham Drassinower, Wendy Gordon, Ed Iacobucci, Bill Kovacic, Vivien Milat, Barak Orbach, Jon Putnam, Eric Rasmusen, Michael Trebilcock, Christopher Yoo, and participants at the annual meetings of the American, Canadian, and Israeli Law and Economics Associations and the Society for Economic Research on Copyright Issues for helpful comments and ideas. All errors, of course, are mine. 
B. Why the Price of Many Intellectual Goods Can Be Expected to

Deviate Substantially from Marginal Cost ...................................856

1. The Marginal Cost of Many Intellectual Goods is Very Low ..........856

2. Pricing Intellectual Goods at Marginal Cost Is Not a Viable

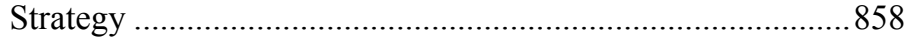

C. "A Presumption of Market Power Has No Empirical Basis"..................860

1. Intellectual Property Is Just Like Any Other Type of Property ........861

2. Most Intellectual Property Rights Have No Commercial Value.......863

D. Choosing the Correct Sample: Disputes Involving Intellectual Property Rights and Market Power .............................................. 864

E. Intellectual Property Rights: Market Power or Rents? ..........................867

Part IV. Perfect, Monopolistic, and Schumpeterian Competition .......................8 872

A. Perfect Competition vs. Monopolistic Competition..............................8 872

B. Schumpeterian Competition............................................................ 873

C. Many Markets for Intellectual Goods are Schumpeterian......................876

Part V. Asking the Correct Questions ............................................................. 880

A. The Return of the Cellophane Fallacy ................................................... 883

B. When Is Existing Market Power Relevant? ........................................ 884

Part VI. Presumptions_-A Short Primer ......................................................... 887

Part VII. Can a Presumption of Market Power Make Sense? .............................891

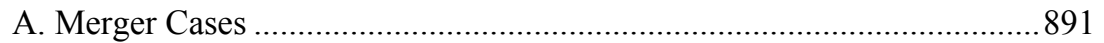

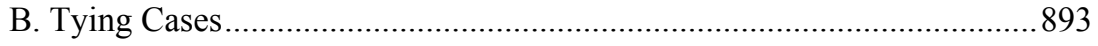

1. Why Was the Presumption Harmful? ..........................................894

2. A Presumption May be Justified Under Alternative Theories of

Harm.

3. A Presumption Could be Defensible Under a Rule of Reason

Analysis for Tying.

C. Enforcement of Invalid Intellectual Property Rights: Walker Process

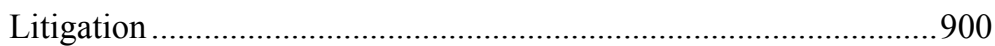

Part VIII. Avoiding Oversized Antitrust Law ................................................... 903

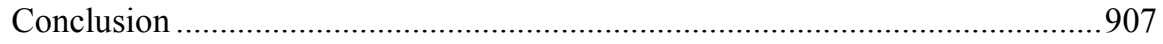




\section{INTRODUCTION}

Do intellectual property ${ }^{1}$ ("IP”) rights confer market power? Do IP rights create "monopolies" or simply confer rights similar to any other form of property? Should courts presume that IP rights confer market power on their owners? Recently, in Illinois Tool Works v. Independent Ink ("ITW"), ${ }^{2}$ the Supreme Court had the opportunity to consider these questions. The Court unanimously held that because IP rights do not necessarily confer market power, courts should not presume that they do, ${ }^{3}$ thus abrogating some of its prior decisions. ${ }^{4}$ Nonetheless, the decision is hardly surprising, as it consciously reflects what has now become conventional wisdom among antitrust lawyers, academics, and policymakers. ${ }^{5}$ The decision is consistent with the Antitrust Guidelines for the Licensing of Intellectual Property ("AGLIP"), issued in 1995 by the U.S. antitrust agencies, in which they proclaimed that they would not presume that IP rights confer market power and that such rights are essentially comparable to any other form of property. ${ }^{6}$ As the Court correctly noted, this view is currently shared by many commentators: it is reflected in "the vast majority of academic literature," and "[i]t is no doubt the virtual consensus among economists."

Two main tenets underlie the "virtual consensus." The first is that the market power conferred by IP rights is qualitatively different from the kind of market power that antitrust law is interested in. The second is an empirical assertion that most IP rights lack any commercial value and hence cannot confer

1. Although parts of this Article might be applicable to legal instruments that fall under the broad rubric of "intellectual property" other than patents and copyrights, the focus of this Article is patents and copyrights and the use of the term "intellectual property" in this Article is, unless otherwise indicated, restricted to these two types of intellectual property.

2. $\quad$ Ill. Tool Works Inc. v. Indep. Ink, Inc. (ITW), 547 U.S. 28 (2006).

3. Id. at $45-46$.

4. Some of these prior decisions include International Salt Co. v. United States, 332 U.S. 392 (1947), United States v. Loew's, Inc., 371 U.S. 38 (1962), and Jefferson Parish Hospital District No. 2 v. Hyde, 466 U.S. 2 (1984). Technically, the ITW decision deals with patents, not with other forms of intellectual property, and relates to tying cases, not necessarily other antitrust issues. However, because patents are often considered to confer greater market power than other forms of IP, it is fair to assume that the holding applies with even greater force to other forms of IP. Similarly, the theoretical foundation of the decision - as will become clearer to the reader - supports the notion that the decision's scope is wider than tying cases.

5. ITW, 547 U.S. at 45-46 ("Congress, the antitrust enforcement agencies, and most economists have all reached the conclusion that a patent does not necessarily confer market power upon the patentee. Today, we reach the same conclusion . . . ."). The ITW Court expressly acknowledged that its "review is informed by the extensive scholarly comment and a change in position by the [antitrust] agencies," id. at 33, and that its "imposition of [the] requirement [to prove market power] accords with the vast majority of academic literature on the subject.," $i d$. at 43 n.4.

6. U.S. Dep'T OF Justice \& Fed. Trade Comm'N, Antitrust Guidelines for THE LiCENSING OF INTELleCtUAL PROPERTY § 2.2 (1995) [hereinafter AGLIP], available at http://www.usdoj.gov/atr/public/guidelines/0558.pdf.

7. $\quad I T W, 547$ U.S. at 43 n.4.

8. $\quad I d$. at 45 . 
any market power upon their owners. Accordingly, IP rights do not generally confer market power in the antitrust sense, and courts should not presume that they do - such a presumption simply does not make sense.

This Article takes issue with the "virtual consensus" and the jurisprudence that it has yielded. Contrary to the "virtual consensus," which dismisses any merit for antitrust law of a presumption that IP rights confer market power, I will argue that three questions must be answered before determining the merit of such a presumption. First, we should conceptually define market power. Second, we should empirically determine whether IP rights confer such market power-how much and how often. And third, we should decide whether courts, as a matter of judicial policy, ought to presume that IP rights confer market power. I will show that the "virtual consensus" is often confused about the first question and therefore fails to address correctly the second. Further, the "consensus" assumes that the answers to these two questions dictate the outcome of the third. In contrast, I posit that IP rights are designed to confer market power upon their holders, that they often do, and that whether courts adjudicating antitrust cases should presume that they do is, first and foremost, a question of judicial policy. The resolution of this question depends on the substantial theory of liability in each case; on the relevant procedural, remedial and evidentiary rules; and on one's preferences about the costs of judicial error. Based on this analysis, a presumption of market power may make sense in some cases but not in others.

Indeed, considerable confusion surrounds the interface between antitrust and IP laws. Regardless of whether antitrust courts presume that IP rights confer market power or create monopolies, the terms "monopoly," "statutory monopoly," "limited monopoly," or "temporary monopolies" are frequently used in relation to IP rights, ${ }^{9}$ and this terminology reflects the fundamental economic understanding of how IP rights function. Standard economic analysis views IP rights, especially patents and copyrights, as legal instruments that create monopolies. ${ }^{10}$ More precisely, this analysis assumes that IP rights are designed to confer upon their owners market power in order to solve a market failure: to allow inventors and creators to recoup their initial investment and account for the risks involved by

9. See, e.g., Metro-Goldwyn-Mayer Studios Inc. v. Grokster, Ltd., 545 U.S. 913, 943 (2005) (Ginsburg, J., concurring) (referring to copyrights as "statutory monopol[ies]" (quoting Sony Corp. of Am. v. Universal City Studios, Inc., 464 U.S. 417, 442 (1984))); id. at 950 (Breyer, J., concurring) (same); Dastar Corp. v. Twentieth Century Fox Film Corp., 539 U.S. 23, 33-34 (2003) ("The rights of a patentee or copyright holder are part of a 'carefully crafted bargain' under which, once the patent or copyright monopoly has expired, the public may use the invention or work at will and without attribution." (citation omitted)); Eldred v. Ashcroft, 537 U.S. 186, 219 (2003) (referring to copyrights as "limited monopolies" and generally throughout the text to patents and copyrights as "monopolies"); Festo Corp. v. Shoketsu Kinzoku Kogyo Kabushiki Co., 535 U.S. 722, 730 (2002) (referring to a patent as a "temporary monopoly"); Fogerty v. Fantasy, Inc., 510 U.S. 517, 526 (1994) (referring to copyrights as "monopoly privileges" and "statutory monopoly") (citing Twentieth Century Music Corp. v. Aiken, 422 U.S. 151, 156 (1975)).

10. See, e.g., F.M. Scherer, Industrial Market Structure and Economic PERFORMANCE 442 (2d ed. 1980) ("Stimulating the invention and development of new products and processes is without doubt the most important benefit expected of the patent system. For it society pays a price: the monopoly power conferred by patent grants."). 
enabling them to set the price of their inventions and works at above the marginal cost. $^{11}$

The standard economic theory of IP begins with the incentive prong. The investment required for the creation of intellectual goods is often high relative to a very low marginal cost of using or making additional copies of them. Therefore, if use or copying were free to all, price would fall to marginal cost. But because marginal cost is lower than the average cost, the original creator would not be able to recover her initial investment and would therefore refrain from making the investment in the first place. ${ }^{12}$ Because they are given a right to exclude others from their work, creators can effect artificial scarcity of their intellectual goods, allowing the price of the intellectual goods to increase and the initial investment to be recouped. ${ }^{13}$ The second prong acknowledges that with IP rights comes social cost. Once an intellectual good has been created, the right to exclude limits access for those users who would pay a price higher than the marginal cost of copying or using the intellectual good but lower than the profit-maximizing price set by the right holder. Excluding such users from the good creates a social loss, which economists often term "deadweight loss." In addition, because the creation of new intellectual goods often builds on previous intellectual goods, increased IP protection may inhibit such cumulative innovation by limiting access to necessary inputs. ${ }^{14}$ IP rights therefore generate a trade-off between incentive and access. IP laws (sometimes with the assistance of antitrust laws) calibrate this trade-off by limiting the length and scope of IP rights and by crafting exemptions to the IP holder's exclusive rights. These laws aim to find the proper incentives for sustained innovation and to minimize the social cost the system imposes. This is, by and large, the basic economic theory of IP laws, as well as their basic legal justification, and although this trade-off between incentive and access does not exhaust all economic and non-economic questions concerning IP, ${ }^{15}$ this story is seldom disputed and serves as the starting point for any further discussion on IP law.

From this perspective, a non-nuanced answer to the question "do IP laws confer market power or create monopolies" seems quite straightforward. "Sure," says the IP lawyer, "the grant of IP rights creates legal monopolies." "Of course," says the economist, "that's what they're all about." But once the economist is pressed to give a more nuanced answer, or the question is presented to an able (and disinterested) antitrust lawyer, a more subtle but rather obscure answer generally arrives: "Yes, but not in an antitrust sense," followed by an attempt to distinguish

11. See, e.g., William M. Landes \& Richard A. Posner, An Economic Analysis of Copyright Law, 18 J. Legal Stud. 325, 327-29 (1989).

12. Id. at 327-28.

13. William M. Landes \& Richard A. Posner, The Economic Structure of Intellectual Property LaW 8 n.28 (2003) (citing ARnOld Plant, The Economic Theory Concerning Patents for Inventions, in SElected ECONOMIC EsSAYS AND AdDresses 36 (1974)).

14. Nancy T. Gallini, The Economics of Patents: Lessons from Recent U.S. Patent Reform, 16 J. ECON. PERSP. 131, 136 (2002).

15. LANDES \& POSNER, supra note 13, at 11. 
between the terms "monopoly," "market power," "substantial market power," and "price above marginal cost."

The confusion is understandable. As a result of the enactment and expansion of antitrust law in the 20th century, the checks on the powers conferred by the grant of IP rights were no longer the exclusive province of IP law. The notion that IP rights were monopolies needed refinement to avoid inevitable conflicts because, as Louis Kaplow noted: "A practice is typically deemed to violate the antitrust laws because it is anticompetitive. But the very purpose of a patent grant is to reward the patentee by limiting competition, in full recognition that monopolistic evils are the price society will pay." in order to deal with two potential problems. One problem is the potential overreach of antitrust law. An assumption that all IP rights are monopolies could potentially expose every IP owner to liability under the antitrust laws, not because having market power is unlawful - it is not- but because having market power is a prerequisite to many antitrust offenses. ${ }^{17}$ This assumption could increase the amount of antitrust litigation involving IP owners, thus causing an increased administrative burden on IP owners and on the judicial system, possibly undermining the value of IP protection in the first place. One solution to this problem reads IP laws as creating an exception to antitrust laws. But this leads to the second potential problem, the potential overreach of IP laws, because such immunity could unduly increase the social costs of IP protection. The history of the intersection between IP and antitrust laws could therefore be read as an attempt to calibrate and recalibrate the tradeoff between the need to provide incentives for innovation and the interest in allowing access to the fruit of such innovations: an exercise in finding the golden mean between the conflicting aims of both sets of laws.

The purpose of this Article is to clarify the relationship between IP rights and market power in order to refine antitrust analysis of IP-related conduct. I will argue that IP rights often confer upon their owners the ability to set prices of intellectual goods at a substantial deviation from marginal cost. In this sense, "the antitrust sense," IP rights often confer market power upon their owners. Although my approach to this point differs from the "virtual consensus," I share the view that IP law and antitrust are not generally at odds, and I share the concern about oversized antitrust scrutiny for IP-related conduct. However, I depart in reasoning: I find that IP law and antitrust law do not inherently conflict with each other not because owners of IP rights do not have market power in the antitrust sense, but despite the fact that they often do. Such inherent conflict does not exist because a seller's existing market power is - or at least should be-irrelevant to most antitrust inquiries. Antitrust should focus on the change in market power resulting from a specific practice or conduct and its effect on welfare, not the existence of market power per se. Therefore, the extent of the initial market power conferred by the IP grant (or otherwise conferred) will only be relevant for antitrust if and when

16. Louis Kaplow, The Patent-Antitrust Intersection: A Reappraisal, 97 HARV. L. REV. 1813, 1817 (1984).

17. Herbert Hovenkamp, Federal Antitrust Policy: The LaW of COMPETITION AND Its Practice $§ 3.1$ (2d ed. 1999). 
a specific practice or conduct increases or maintains the involved parties' market power. Thus, only if an antitrust defendant's conduct exerts an anticompetitive effect could the antitrust defendant's existing power matter.

I will argue that much of the confusion about IP and market power, and about the presumption of market power, results from failing to ask the correct questions and from attempts to analyze questions of IP, market power, and antitrust in isolation from the specific actual antitrust questions being examined. This failure leads to an inability to distinguish between situations in which the market power conferred by IP rights is relevant and those in which it is not, and consequently to an inability to determine when a presumption, as a judicial instrument, makes sense.

I do not purport to suggest that my approach solves all the potential tensions between IP and antitrust; many questions remain unresolved. Nor do I argue that the AGLIP framework, a cornerstone of the "virtual consensus" is not useful. For the majority of cases it is. Yet at the margin, my approachacknowledging that market power likely exists in many disputes that involve IPprovides a better starting point to tackle the unresolved issues at the intersection of IP and antitrust than the AGLIP approach, which simply denies such a linkage and suggests that in the rare cases when market power exists antitrust adequately handles it. ${ }^{18}$

This Article begins by briefly describing how the legal approach toward the relationship between IP, market power, and antitrust developed from the early days of antitrust to the contemporary view that IP rights do not confer market power in an antitrust sense. I then argue that the contemporary view-the "antipresumption" of market power-is misguided and explain why the price of many intellectual goods can be expected to deviate substantially from marginal cost. I then show that much of the confusion results from attempts to analyze questions of IP, market power, and antitrust in isolation from the specific actual antitrust questions examined and how identifying the correct question allows us to decide when market power conferred by IP rights is relevant. Next, after explaining what legal presumptions are and what they are used for, I demonstrate the merits and demerits of using a rebuttable presumption of market power in three types of cases: merger cases, tying cases, and cases involving attempts to enforce invalid IP rights. Before concluding, I explain why my proposed analytical framework should not lead to oversized antitrust scrutiny of IP related conduct.

\section{A Concise History of the Presumption of Market Power in the Antitrust-Intellectual Property ConteXt}

\section{A. The Early Years}

Willard Tom and Joshua Newberg have identified three periods of the intersection between antitrust and IP laws in American jurisprudence. ${ }^{19}$ The first

18. See AGLIP, supra note 6, $§ 2.1$ (“'G]eneral antitrust principles [apply] to conduct involving intellectual property ....").

19. Willard K. Tom \& Joshua A. Newberg, Antitrust and Intellectual Property: From Separate Spheres to Unified Field, 66 ANTITRUST L.J. 167, 168 (1997). 
period began with the enactment of the Sherman Act in 1890 and lasted for about two decades ${ }^{20}$ the second period began in the mid 1910s and lasted until the mid $1970 \mathrm{~s},{ }^{21}$ and the third period began in the mid 1970s, culminating in the issuance of the AGLIP in $1995 .^{22}$ During the first and second periods, courts perceived the existence of an inherent conflict between patent (and later other IP) laws and antitrust laws. In both periods, courts viewed patent and copyright laws as granting monopolies, although they differed substantially in their views on the proper scope of these monopolies. ${ }^{23}$ While the tendency of courts in the first period was to define the scope of patents generously in a way that covered any anticompetitive result that the patent holder could achieve by using her patent right, ${ }^{24}$ the second period emphasized patent rights as exceptions to the general rules governing the free market economy, exceptions that must be narrowly construed. ${ }^{25}$ The first period essentially treated any patent-related practice as per se legal, regardless of any subsequent anticompetitive effect. The second period shared the same perception of per se legality - but only so long as the practice fell within the scope of the IP right as defined by the court. Per se illegality was then attributed to any practice beyond that scope regardless of any procompetitive effect that might have resulted. ${ }^{26}$

Despite different rules and different results, in both eras courts presumed that IP rights conferred market power upon their owners. The difference came in the normative consequences resulting from that presumption. In the first period, any exercise of this market power was deemed legal per se, while in the second period courts were quite willing to find IP owners liable for antitrust violations by presuming that IP rights conferred upon their owners enough market power to trigger such liability. ${ }^{27}$ In 1902, for example, in E. Bement \& Sons v. National Harrow Co., a leading case of the first era, the U.S. Supreme Court upheld a pricefixing cartel formed by competing patent holders, noting that:

\begin{abstract}
the general rule is absolute freedom in the use or sale of rights under the patent laws of the United States. The very object of these laws is monopoly, and the rule is, with few exceptions, that any conditions which are not in their very nature illegal with regard to this kind of property, imposed by the patentee and agreed to by the licensee for the right to manufacture or use or sell the article, will be upheld by the courts. The fact that the conditions in the contracts keep up the monopoly or fix prices does not render them illegal. ${ }^{28}$
\end{abstract}

Sixty years later, in United States v. Loew's, Inc., the Court, in the context of an illegal-tying claim, ruled that "[t]he requisite economic power [necessary for a finding of an antitrust violation] is presumed when the tying product is patented or

$\begin{array}{ll}20 . & \text { Id. at } 168-70 . \\ 21 . & I d . \text { at } 170-73 . \\ 22 . & I d . \text { at } 173-75 . \\ 23 . & I d . \text { at } 168-73 . \\ 24 . & \text { Id. at } 170 . \\ 25 . & \text { Id. at } 172 . \\ 26 . & \text { Id. } \\ 27 . & \text { See id. at } 168-73 . \\ 28 . & \text { 186 U.S. } 70,91(1902) .\end{array}$


copyrighted." ${ }^{29}$ Furthermore, the Court in Loew's added that the copyrighted works in question were distinctive enough to render the existence of competing content irrelevant when determining whether the antitrust laws were violated. ${ }^{30}$

\section{B. The Nine No-No's}

The culmination of the approach during the second era formed what came to be known as the "Nine No-No's." 31 These were a series of IP licensing practices that the Antitrust Division of the U.S. Department of Justice considered per se unlawful and likely to attract scrutiny. ${ }^{32}$ In creating a list of generally suspect practices, the Nine No-No's reflected two perceptions of that era. The first was the notion that IP rights conferred market power upon their owners, and the second was that many restrictions imposed by IP owners on their licensees were likely anticompetitive.

Toward the end of the 1970s, the Antitrust Division began to change its approach. ${ }^{33}$ The growing influence of the Chicago School on economics and antitrust analysis and its view that maximizing net efficiency gains should be the primary concern of antitrust policy had impacted the Division's approach to antitrust analysis in many areas including IP. ${ }^{34}$ It became acknowledged that many

29. 371 U.S. 38, 45 (1962) (citation omitted), abrogated by Ill. Tool Works Inc. v. Indep. Ink, Inc. (ITW), 547 U.S. 28, 31 (2006).

30. Id. at 49 .

31. The Nine No-No's have never been articulated in a written document or guidelines and were announced in a series of public speeches by senior officials of the Department of Justice, Antitrust Division. See Tom \& Newberg, supra note 19, at 178-79. They became known as the Nine No-No's after a speech by Deputy Assistant Attorney General Bruce Wilson. The Nine No-No's include: tying unpatented materials to the patent; mandatory grantbacks to the licensor of patents issued to the licensee; restriction on resale of the patented product; restrictions on the licensee's freedom to deal with others; agreement by the licensor not to license to others; mandatory package licensing; royalties unrelated to the sales of the patented item; restrictions on sales of unpatented products made by a patented process; and resale price maintenance. Richard Gilbert \& Carl Shapiro, Antitrust Issues in the Licensing of Intellectual Property: The Nine No-No's Meet the Nineties, 1997 Brookings PAPERS ON ECON. ACtivity, Microeconomics 283, 285; Tom \& Newberg, supra note 19, at 179-81.

32. See Bruce B. Wilson, Deputy Assistant Attorney Gen., Patent LicensingPer Se Violations, Remarks Before the Annual Joint Meeting of the Michigan State Bar Antitrust Law Section and the Patent Trademark and Copyright Law Section in Detroit (Sept. 21, 1972), [Current Comment Transfer Binder 1969-1983] 5 Trade Reg. Rep. (CCH) I 50,146, at 55,248 (1972) (reiterating that the Nine No-No's were viewed as illegal per se, while rule of reason was applied to other patent licensing matters). But see Tom \& Newberg, supra note 19, at 179 (noting that there is some dispute as to whether every NoNo was understood by the Division to be illegal per se).

33. See, e.g., Ky P. Ewing, Jr., Deputy Assistant Attorney Gen., PatentAntitrust-Antitrust Division Enforcement, Remarks Before the San Francisco Patent Law Association, Pebble Beach, Cal. (May 5, 1979), [Current Comment Transfer Binder 19691983] 5 Trade Reg. Rep. (CCH) 50,398, at 55,887 (1979) (denouncing the impression that the Division viewed the Nine No-No's as per se illegal restrictions).

34. For a concise exposition of the Chicago School approach to antitrust, see HOVENKAMP, supra note 17, § 2.2(b). 
restrictions on competition, often part of any IP licensing agreement, could indeed be efficient and welfare increasing and therefore not raise any antitrust concerns. Finally, in 1981, the Division proclaimed the burial of the Nine No-No's. In a public speech before the American Bar Association Antitrust Section, Deputy Assistant Attorney General Abbott B. Lipsky, Jr. announced that "the 'Nine NoNo's,' as statements of rational economic policy, contain more error than accuracy." $" 35$ In his speech, Lipsky noted that his analysis of IP-related conduct non-coincidently bore strong thematic resemblance to the Division's change in approach toward vertical restraints in other, non-IP contexts. ${ }^{36}$ A new period had begun.

\section{Building a "Virtual Consensus": From Presumption to Anti-Presumption}

The approach in the third period reflected a shift in the understanding of the relationship between antitrust and IP laws. Antitrust and IP laws were no longer viewed as conflicting statutory schemes but rather as complementary policies within a harmonized legal system. ${ }^{37}$ Both policies apparently shared the same economic goals: "to maximize wealth by producing what consumers want at the lowest cost" 38 and "encourag[e] innovation, industry and competition." 39 The AGLIP formed the highlight of this new approach. ${ }^{40}$ This modern approach treats IP as essentially comparable to any other form of property. ${ }^{41}$ In contrast to earlier courts' decisions, no presumption of market power is inherent in the mere possession of IP, ${ }^{42}$ and licensing of IP "allows firms to combine complementary factors of production and is generally procompetitive." 43

As Tom and Newberg explain, this new approach effectively repudiates the former one. ${ }^{44}$ Because IP "is comparable to any other form of property . . . , there is no invisible, magic line surrounding the intellectual property kingdom, the crossing of which automatically leads to antitrust penalties." 45 A finding of an antitrust violation therefore depends upon the existence of anticompetitive effect, the determination of which usually requires analysis of the specific market conditions and a finding of market power. Furthermore, if an IP right is not presumed to confer market power, then a full inquiry into the market and the availability of substitutes is required. ${ }^{46}$ The obvious, stated result of that approach

35. Abbott B. Lipsky, Jr., Current Antitrust Division Views on Patent Licensing Practices, 50 ANTITRUST L.J. 515, 517 (1982) (text of remarks before the American Bar Association Antitrust Section, Washington, D.C. (Nov. 5, 1981)).

36. Id.

37. See Tom \& Newberg, supra note 19, at 173-74.

38. Ward S. Bowman, Jr., Patent and Antitrust Law: A Legal and ECONOMIC APPRAISAL 1 (1973).

39. Atari Games Corp. v. Nintendo of Am., Inc., 897 F.2d 1572, 1576 (Fed. Cir. 1990).

40. Tom \& Newberg, supra note 19, at 173-74.

41. $\quad$ AGLIP, supra note $6, \S 2.0$.

42. $\quad I d . \S 2.2$.

43. Id. $\S \S 2.0,2.3$.

44. Tom \& Newberg, supra note 19, at 174.

45. Id.

46. Id. 
is that many practices, especially licensing restrictions, that could have been held illegal under the old approach are now presumed procompetitive, hence lawful, at least until a plaintiff, bearing the burden of proof, can demonstrate otherwise. This approach also influenced competition agencies in other jurisdictions. ${ }^{47}$

However, the AGLIP's approach appears to go far beyond that. The AGLIP seem to go beyond simply embracing and advocating rule-of-reason analysis in departure from an earlier jurisprudence characterized by per se rules. Indeed, the Antitrust Division already recognized this shift by the early 1980s, as Lipsky's speech clearly demonstrates. ${ }^{48}$ Yet, that speech and the AGLIP, although reaching similar conclusions, rely on different assumptions. In his speech, Lipsky concurred with the notion that IP rights confer market power, ${ }^{49}$ but assumed that "there is nothing inherently wrong or anticompetitive about the market power conferred by a patent grant ... [because] it is safe to presume that whatever market power may arise from possession of the exclusive right to make, use, or sell has been earned by useful inventive activity. ${ }^{, 50}$ Furthermore, Lipsky assumed that "the value of the patent monopoly arises from the patentee's ability to exploit his patent-based market power." ${ }^{, 51}$ In Lipsky's view, "[t]hese two basic assumptions seem to lie beyond the realm of useful debate." 52

In 1995, however, the Antitrust Division and the FTC seemed to have debated these very assumptions. The AGLIP offer a completely different view of the relationships between antitrust and IP rights. In Lipsky's view, there is nothing inherently wrong or anticompetitive about the market power conferred by a patent grant, and even if the congressional decision to reward invention in this way could be debatable, as a matter of policy, "antitrust analysis . . . is bound to accept the legality of the patent holder's monopoly position." ${ }^{53}$ The AGLIP agree that having market power is not inherently unlawful, but a close reading reveals that in their view this is not an issue because, in most cases, such market power does not exist. ${ }^{54}$ The AGLIP's first general principle is that "for the purpose of antitrust

47. In 2000, the Canadian Competition Bureau issued guidelines reflecting the same perspective. According to the Canadian guidelines, "IP laws and competition laws are two complementary instruments of government policy that promote an efficient economy." Competition Bureau, Intellectual Property Enforcement Guidelines 1 (2000), available at http://strategis.ic.gc.ca/pics/ct/ipege.pdf. Echoing the same perspective, guidelines issued in 2004 by the European Commission maintain that "there is [no] inherent conflict between intellectual property rights and the [European] Community competition rules. Indeed, both bodies of law share the same basic objective of promoting consumer welfare and an efficient allocation of resources." EUROPEAN COMM'N, COMMISSION NOTICE: Guidelines on the APPLiCATION OF ARTiCle 81 OF THE EC TREATY TO TEChNOLOGY TRANSFER AGREEMENTS 101/2 (2004), available at http://eur-lex.europa.eu/LexUriServ/site/ en/oj/2004/c_101/c_10120040427en00020042.pdf.

48. Lipsky, supra note 35.

49. To be precise, Lipsky's speech is only about patents, not about copyright or other forms of IP. See generally id.

50. Id. at 516 .

51. $\quad I d$.

52. Id.

53. $I d$.

54. AGLIP, supra note 6, § 2.2. 
analysis [IP rights are regarded as] essentially comparable to any other form of property," ${ }^{25}$ and although IP law "bestows on the owners of intellectual property certain rights to exclude others," an IP owner's "rights to exclude are similar to the rights enjoyed by the owners of other forms of private property." ${ }^{, 56}$ In the same vein, the AGLIP's second general principle is that "the Agencies do not presume that intellectual property creates market power in the antitrust context." 57 The AGLIP further elaborate on this statement, explaining that "the Agencies will not presume that [an IP right] necessarily confers market power upon its owner"s8 because, "although the intellectual property right confers the power to exclude with respect to the specific product, process or work in question, there will often be sufficient actual or potential close substitutes ... [that] prevent the exercise of market power." 59 Conjoining this principle with the first, the AGLIP conclude: "Intellectual property is . . . neither particularly free from scrutiny under the antitrust laws, nor particularly suspect under them."60 Therefore, while both Lipsky and the AGLIP do not consider IP as inherently suspect, their grounds are entirely different. Lipsky considers the market power inherent in IP rights as essentially benign, whereas the AGLIP maintain that on economic grounds, as a general matter, no such market power exists.

To be sure, the presumption that IP rights necessarily confer market power (to the extent that it had ever been robust) had been eroded by some courts long before the AGLIP were promulgated. For example, as early as 1965, the U.S. Supreme Court, in Walker Process Equipment, Inc. v. Food Machinery \& Chemical Corp., refused to infer market power necessary for a monopolization claim from the mere existence of a patent. ${ }^{61}$ In remanding the case, the Court explained:

it would . . . be necessary to appraise the exclusionary power of the ... patent claim in terms of the relevant market for the product involved. Without a definition of that market there is no way to measure [the patent owner's] ability to lessen or destroy competition. It may be that the [patented] device . . . does not comprise a relevant market. There may be effective substitutes for the device which do not infringe the patent. This is a matter of proof ....6

Similarly, in Jefferson Parish Hospital District No. 2 v. Hyde, although the majority repeated the view that "if the government has granted the seller a patent or similar monopoly over a product, it is fair to presume that the inability to buy the product elsewhere gives the seller market power, ${ }^{, 63}$ four concurring Justices

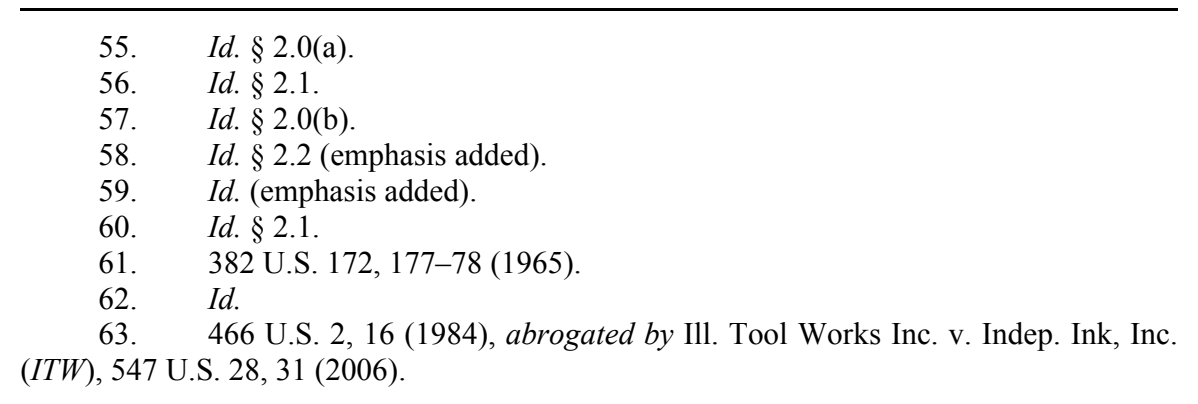


stated that it is a "common misconception" to presume that "a patent or copyright, a high market share, or a unique product" by itself demonstrates market power. ${ }^{64}$ As Justice O'Connor explained:

While each of these three factors might help to give market power to a seller, it is also possible that a seller in these situations will have no market power: for example, a patent holder has no market power in any relevant sense if there are close substitutes for the patented product. $^{65}$

Yet, the AGLIP go beyond simply stating that a presumption of market power is inappropriate because there could be instances in which the existence of close substitutes would prevent the exercise of market power by IP owners. Such reasoning would not be inconsistent with a presumption of market power, as long as the presumption is rebuttable. ${ }^{66}$ By invoking a substantial similarity between IP and other forms of property, and the similar right of each type of property owners to exclude others, and by stating that there will often be sufficient actual or potential close substitutes to every IP protected product, process, or work, the AGLIP reject any special connection between IP and market power. Therefore, the AGLIP essentially adopt an "anti-presumption"- - a presumption that IP rights do not confer market power upon their owners.

The AGLIP approach aligns with the views of many contemporary commentators. The presumption of market power has been rejected, even scorned, by a wide range of lawyers and scholars. Professor Hovenkamp sums up this view: "[T]o presume market power in a product simply because it is protected by intellectual property is nonsense."67 According to Areeda and Hovenkamp, "market power cannot be inferred, even presumptively, from the possession of intellectual property" because "[a] trademark, copyright, or patent excludes others

64. Id. at 38 n.7 (O'Connor, J., concurring).

65. Id.

66. There has never been clear guidance on the issue. According to Hovenkamp et al., the presumption is rebuttable. HERBERT HOvENKAMP ET AL., IP AND ANTITRUST: AN Analysis of Antitrust Principles Applied to Intellectual Property LAW § 4.2(e)(7) (2002); see also Digidyne Corp. v. Data Gen. Corp., 734 F.2d 1336, 1344 (9th Cir. 1984) ("The RDOS [software] copyright created a presumption of economic power sufficient to render the tying arrangement illegal per se. The burden to rebut the presumption shifted to defendant."). In Digidyne, however, the court restricted the ability of the defendant to provide evidence to rebut the presumption. 734 F.2d at 1345. The court concluded that "the mere presence of competing substitutes for the tying product, here taking the form of other programming material as well as other feature films, is insufficient to destroy the legal, and indeed the economic, distinctiveness of the copyrighted product." Id. (quoting United States v. Loew's, Inc., 371 U.S. 38, 49 (1962), abrogated by Ill. Tool Works Inc. v. Indep. Ink, Inc. (ITW), 547 U.S. 28, 31 (2006)). But see Indep. Ink., Inc. v. Ill. Tool Works Inc., 396 F.3d 1342, 1352 (Fed. Cir. 2005) (reaffirming the existence of the presumption of market power in tying cases but clarifying that it is rebuttable, yet stressing that " $\mathrm{t}] \mathrm{h}$ he presumption can only be rebutted by expert testimony or other credible economic evidence of the crosselasticity of demand, the area of effective competition, or other evidence of lack of market power"), vacated, 547 U.S. at 46.

67. HovENKAMP, supra note 17, §3.9(d) (conceding, however, that the presence of intellectual property is not absolutely irrelevant to market power questions). 
from duplicating the covered name, word, or product (etc.) but does not typically exclude rivals from the market." 68

Reflecting this approach, several legislative initiatives to overrule the presumption have been pursued. In 1988, Congress indirectly overruled the presumption in the related doctrine of patent misuse ${ }^{69}$ by amending the Patent Act. ${ }^{70}$ The amendment added section 271(d)(5), which provides that a patentee shall not be denied relief or deemed guilty of misuse or illegal extension of the patent right in certain tying cases "unless, in view of the circumstances, the patent owner has market power in the relevant market for the patent or patented product on which the license or sale is conditioned." ${ }^{, 71}$

The requirement that patent misuse be based on the existence of market power, while hardly contentious, reflects an assumption that not all patents confer market power on their owners as well as a policy choice to err in favor of patent holders, rather than on the side of patent infringers. In addition, in 1989 and 1995, the Judiciary Committee of the House of Representatives considered proposals to restrain courts hearing antitrust cases from drawing a presumption of a relevant market or the existence of market power on the mere basis of the possession of a patent or copyright. ${ }^{72}$ Although no legislation has been enacted, such initiatives occasionally recur. ${ }^{73}$ Although the ITW Court rejects the presumption by using the

68. 2A Phillip E. Areeda \& Herbert Hovenkamp, Antitrust law: An ANAlysis of ANTITRUST Principles AND Their APPLiCATION 138 (2d ed. 2002). Nancy Gallini and Michael Trebilcock argue that there should not be a presumption that intellectual property rights create market power because it is an "important, well-known point that the scope of a patent is not commensurate with an antitrust market," as most "products and processes face a large number of substitutes." Nancy T. Gallini \& Michael J. Trebilcock, Intellectual Property Rights and Competition Policy: A Framework for the Analysis of Economic and Legal Issues, in COMPETITION POLICY AND INTELleCtuAL Property Rights IN THE Knowledge-Based Economy 17, 22 (Robert D. Anderson \& Nancy T. Gallini eds., 1998). In Edmund Kitch's view, the assumption that IP rights confer economic monopoly is an "elementary but persistently repeated error[]." Edmund W. Kitch, Elementary and Persistent Errors in the Economic Analysis of Intellectual Property, 53 VAND. L. REV. 1727, 1729 (2000).

69. Patent misuse usually refers to an affirmative defense to an action of patent infringement or for royalties under a license, which may apply when the patentee's conduct is regarded as an improper attempt to "extend" the scope of the patent, or violates the antitrust laws. If misuse is found, the patent is rendered unenforceable until the misuse is "purged." George Gordon \& Robert J. Hoerner, Overview and Historical Development of the Misuse Doctrine, in ABA Section of Antitrust Law, Intellectual Property Misuse: LiCENSING AND LiTIGATION 1-2 (2000).

70. Act of Nov. 19, 1988, Pub. L. No. 100-703, § 201, 102 Stat. 4674, 4676 (1988) (codified as amended at 35 U.S.C. $§ 271(d)(2006)$ ).

71. 35 U.S.C. $\S 271(\mathrm{~d})(5)$.

72. Intellectual Property Antitrust Protection Act of 1989, H.R. 469, 101st Cong., 2d Sess. (1989); The Intellectual Property Antitrust Protection Act of 1985, H.R. 2674, 104th Cong., 2d Sess. (1996).

73. See Intellectual Property Litigation: Hearing on H.R. 2674 Before the Subcomm. on Courts, the Internet and Intellectual Property of the H.Comm. on the Judiciary, 107th Cong. (2001) (Statement of Charles P. Baker, Chair, American Bar Association Section of Intellectual Prop. Law), available at http://www.abanet.org/ 
language "not necessarily confer market power"74 (a la Walker Process and the minority in Jefferson Parish), the Court's repeated reference to the "virtual consensus" suggests that the Court has adopted a more expansive view, similar to the AGLIP's "anti-presumption." The conclusion that the Court has adopted this view is strengthened by its holding that the prohibition on tying arrangements should be restricted to only those cases where "such arrangements . . . are the product of a true monopoly." 75 This view is reminiscent of the AGLIP view that IP rights are generally not "true monopolies."

\section{The Denialists' Puzzle}

The denialist approach to the connection between IP and market powerrepresented by the AGLIP, shared by other commentators, and now adopted by the Supreme Court-seems, at least on its face, inconsistent with the economic analysis of IP. After all, economic analysis of IP often assumes that IP rights do confer market power in the sense of enabling their holders to set a price above marginal cost in order to recover the fixed cost of creation. ${ }^{76}$

In addition, the denialists' approach seems inconsistent with a significant body of IP law that imposes limitations on IP owners, attempting to minimize the social cost associated with IP. Simply put, if IP rights do not confer market power, and if close substitutes are generally abundant, who cares if IP rights are perpetual? If copyrighted works are generally priced at the competitive level, what difference does it make if the copyright owner can or cannot control the distribution of her works after the first sale ${ }^{77}$ Why worry about fair use $?^{78}$

intelprop/marketpower.pdf; Comm. on Antitrust \& Trade Regulation, Antitrust "Market Power" and Intellectual Property: Why FTC and DOJ Action is Necessary, 58 THE RECORD 10,10 (2003).

74. Ill. Tool Works Inc. v. Indep. Ink, Inc. (ITW), 547 U.S. 28, 45 (2006) (emphasis added).

75. Id. at $42-43$.

76. See, e.g., Landes \& Posner, supra note 11, at 327 ("Since the decision to create the work must be made before the demand for copies is known, the work will be created only if the difference between expected revenues and the cost of making copies equals or exceeds the cost of expression.”). Stanley M. Besen stated:

During the period of protection, the competition faced by the innovator is limited and he is thus able to earn supranormal returns that permit him to cover the costs and risks of undertaking the search for the innovation. The extent to which the innovator is sheltered from competition depends on both the scope of protection and the availability of imperfect substitutes for the innovation.

Stanley M. Besen, Intellectual Property, in 2 The New Palgrave Dictionary of ECONOMICS AND THE LAW 348 (Peter Newman ed., 1998). Besen's use of the term "supranormal returns" is probably inaccurate. The purpose of IP rights is to allow the innovator to set prices above marginal cost in order to cover the costs and risks of undertaking the search for the innovation. This does not require, and there is no reason to assume, that the return on the investment will be "supranormal."

77. For more detailed discussion on IP law's built-in tools to control market power, see Thomas F. Cotter, The Procompetitive Interest in Intellectual Property Law, 48 WM. \& MARY L. REV. 483 (2006). 
Market-power denialists have not ignored this potential inconsistency and many of them offer one or more explanations in an attempt to resolve this tension. Unfortunately, many of these attempts, discussed below, while clarifying some important points, ultimately lead to more confusion than clarity. Even worse, if IP and market power are inherently connected, as I shall establish below, then the denialist approach and the resulting anti-presumption may lead to two types of potential errors. One type of error is that without a presumption of market power, the burden on antitrust plaintiffs challenging IP conduct could increase, resulting in fewer challenges to some practices of IP holders. Depending on one's view of the social benefits and costs of IP rights and on the magnitude of the cost of erroneous decisions, this increased burden may be a vice or a virtue. ${ }^{79}$ The other type of error lies in the potential condemnation of too many IP related practices because at least in the absence of an alternative definition of market power, many IP owners may be found to possess significant market power, regardless of the anti-presumption. In this sense, if the purpose of the anti-presumption has been to create a safer haven for IP owners (compared to the approach of the Agencies toward IP-related restraints in the previous era), in the expectation that this would stimulate innovation and dissemination of knowledge, the unintended result of this approach could be a trap. Although the anti-presumption creates a procedural safehaven by placing the burden to prove market power on plaintiffs, courts may assume that those cases where market power is proved are indeed exceptional and do warrant antitrust relief.

\section{The Attempts to Resolve the Puzzle}

Faced with the tension between the economic theory of IP rights and the denialists' view that a presumption of market power is wrong, market-power denialists offer several arguments, often intermingled with each other, to resolve this puzzle. The first argument states that IP rights do confer some market power, but "not in an antitrust sense." This definitional argument is usually combined with the second argument-an empirical assertion that most intellectual goods have many close substitutes. The third argument, closely related to the first and the second, is that an IP holder's right to exclude does not differ from that of a

78. It is not my intention to reduce all those limitations and doctrines to the single issue of market power. Clearly, many of them have other justifications, economic and non-economic. See, e.g., Wendy J. Gordon, Excuse and Justification in the Law of Fair Use: Commodification and Market Perspectives, in THE COMMODIFICATION OF INFORMATION 149 (Niva Elkin-Koren \& Neil W. Netanel eds., 2002) (discussing transaction costs and other justifications for fair use). However, it seems to me that the significance of such limitations would be much smaller if the exercise of market power had not been an important concern. For example, the proposition that fair use permits uses when the transaction costs of licensing exceed the value of the use implicitly assumes that the market price set by the copyright holder for the licensed uses exceeds the marginal cost of accessing the work.

79. Because we do not know whether, from an overall social standpoint, current IP regimes provide too much or too little protection, it is hard to assess the benefit of increasing IP holders' potential antitrust liability. Increased antitrust liability may be beneficial if current IP regimes are excessive and vice versa. For a discussion of the costs of error, see Cotter, supra note 77. 
tangible property owner. The fourth argument is based on the empirical assertion that most IP rights have no commercial value whatsoever and therefore cannot possibly entail any market power. A fifth argument is that IP rights, at most, confer rents, but not market power. I examine these arguments in turn.

\section{A. "Market Power in the Antitrust Sense"}

Professor Lemley provides a typical exposition of the first argument. He explains:

In economic terms, intellectual property rights prevent competition in the sale of the particular work or invention covered by the intellectual property right, and therefore allow the intellectual property owner to raise the price of that work above the marginal cost of reproducing it. . . This means that in many cases fewer people will buy the work than if it were distributed on a competitive basis, and they will pay more for the privilege. ${ }^{80}$

But then he immediately adds, "[t]his does not mean that intellectual property rights automatically confer market power or create 'monopolies' in an economic or antitrust sense, as some courts have erroneously presumed." ${ }^{\prime 1}$ However, Lemley neither defines what "market power" or "monopoly" are, nor explains why IP rights' ability to restrict competition and raise prices is not synonymous with the term "monopoly" in its economic or antitrust sense. ${ }^{82}$

The AGLIP, adopting a similar view, ${ }^{83}$ do define the term market power. They explain market power as "the ability profitably to maintain prices above, or output below, competitive levels for a significant period of time." 84 Although the sentence contains an ambiguous term, "the competitive level," this ambiguity should not be much of a difficulty for an antitrust lawyer or antitrust economist. In fact, this is the classic definition of market power used in antitrust law. The same definition can be found in the Horizontal Merger Guidelines, ${ }^{85}$ and it is often used

80. Mark A. Lemley, The Economics of Improvement in Intellectual Property Law, 75 TEX. L. REV. 989, 996 (1997).

81. Id. at 996 n.26.

82. To illustrate the confusion: Lemley distinguishes between market power in an "economic or antitrust sense" on one hand and some "other" sense on the other, thus viewing the economic sense and antitrust sense as synonyms. See id. Klein and Wiley, however, make a similar substantive argument but instead suggest that the distinction should be made between market power in economics and market power in antitrust. Benjamin Klein \& John Shepard Wiley Jr., Competitive Price Discrimination as an Antitrust Justification for Intellectual Property Refusals to Deal, 70 ANTITRUST L.J. 599, 624-29 (2003).

83. AGLIP, supra note $6, \S 2.0($ b) ("[T]he Agencies do not presume that intellectual property creates market power in the antitrust context ....").

84. Id. $§ 2.2$.

85. U.S. Dep't of Justice \& Fed. Trade Comm'n, Horizontal Merger GUIDELINES $\S 0.1$ (1997), available at http://www.usdoj.gov/atr/public/guidelines/hmg.pdf. The Merger Guidelines explain that "[i]n some circumstances, a sole seller (a "monopolist") of a product with no good substitutes can maintain a selling price that is above the level that would prevail if the market were competitive." Id. However, the ultimate question of 
by courts ${ }^{86}$ and by many commentators. ${ }^{87}$ Therefore, the term "the competitive level," despite its apparent ambiguity, has a rather clear meaning in antitrust: price equals marginal cost. For example, this definition opens Landes and Posner's classic article "Market Power in Antitrust Cases," term "the competitive level" means that price equals marginal cost. ${ }^{89}$ This definition is usually accompanied by a caveat, that for antitrust law not every deviation of the price from marginal cost carries legal significance because "the fact of market power must be distinguished from the amount of market power." 90 And " $[\mathrm{w}]$ hen the deviation of price from marginal cost is trivial, or simply reflects certain fixed costs, there is no occasion for antitrust concern, even though the firm has market power in our sense of the term." ${ }^{.91}$ In addition, antitrust tradition acknowledges that, in practice, markets are never perfectly competitive, and prices are usually set somewhere above marginal cost. This is particularly true when the products in a market are differentiated because some consumers will have stronger preferences for one product over another and sellers will have some control over price. Yet, as Posner put it:

merger analysis is the effect of the proposed merger on market power- "whether the merger is likely to create or enhance market power or to facilitate its exercise." Id. $\S 0.2$.

86. See, e.g., NCAA v. Bd. of Regents of Univ. of Okla., 468 U.S. 85, 109 n.38 (1984) ("Market power is the ability to raise prices above those that would be charged in a competitive market." (citations omitted)); Jefferson Parish Hosp. Dist. No. 2 v. Hyde, 466 U.S. 2, 27 n.46 (1984), abrogated by Ill. Tool Works Inc. v. Indep. Ink, Inc. (ITW), 547 U.S. 28, 31 (2006) ("As an economic matter, market power exists whenever prices can be raised above the levels that would be charged in a competitive market.").

87. See, e.g., AREEDA \& HovENKAMP, supra note 68, at 90 ("For antitrust purposes, therefore, market power is the ability (1) to price substantially above the competitive level and (2) to persist in doing so for a significant period without erosion by new entry or expansion. This is the meaning — though not the literal wording — of a standard legal formula.").

88. William M. Landes \& Richard A. Posner, Market Power in Antitrust Cases, 94 HARV. L. REV. 937, 937 (1981).

89. Id. at 941, 974; see also Dennis W. Carlton \& JefFrey M. Perloff, MODERN INDUSTRIAL ORGANIZATION 610 (3d ed. 1999) (“A firm . . . has market power if it is profitably able to charge a price above that which would prevail under competition, which is usually taken to be marginal cost."). Additionally, Herbert Hovenkamp stated:

Market power is a firm's ability to deviate profitably from marginal cost pricing. Further, marginal cost, or competitive, pricing is an important goal of the antitrust laws. Marginal cost is therefore a useful base from which to measure market power: the greater the ratio of a firm's profitmaximizing price to its marginal cost, the more market power the firm has.

HovenKAMP, supra note $17, \S 3.1(\mathrm{a})$.

90. Landes \& Posner, supra note 88, at 939 (emphasis added); see also AREEDA \& HOVENKAMP, supra note 68, at 90.

91. Landes \& Posner, supra note 88, at 939 (footnote omitted). The last point, that there is no occasion for concern if the deviation from marginal cost reflects certain fixed costs, is fundamental for properly identifying the antitrust concerns in the context of IP rights. I will return to it later when discussing the normative consequences of the existence of market power. 
[T]o infer that every seller who faces a downward-sloping demand curve has monopoly power in a sense interesting to antitrust law would be a profound mistake. In fact most sellers of nonfungible commodities do not face a completely horizontal demand curve; but when it is almost horizontal, the reduction in output (and rise in price) that result from the seller's reducing his output from the competitive level to the point at which marginal revenue equals marginal cost will be too slight to worry about. ${ }^{92}$

Therefore, in the antitrust tradition, the terms "monopoly power" or "market power" refer to situations in which prices are set at a substantial deviation from marginal cost and exclude situations of trivial deviations. "Market power" in "the antitrust sense" will therefore be shorthand for "substantial" market power, that is, an ability to set prices substantially above marginal cost, and the fact of market power, so defined, is distinct from the question whether and when antitrust should worry about it.

With a clear definition of market power in the antitrust sense, it is easier to understand the AGLIP and reconcile what could otherwise be seen as two contradictory statements. In section 1.0, the AGLIP explain, "[i]n the absence of intellectual property rights, imitators could more rapidly exploit the efforts of innovators and investors without compensation. Rapid imitation would reduce the commercial value of innovation and erode incentives to invest, ultimately to the detriment of consumers." 94 In other words, the AGLIP share the view that IP laws are designed to prevent "rapid imitation" (i.e., restrict competition) that would "reduce the commercial value of innovation" (i.e., the price that could be charged for it). ${ }^{95}$ This view seems consistent with the view that IP rights $d o$ confer market power. But the AGLIP maintain that IP rights do not necessarily confer market power in the antitrust sense. ${ }^{96}$ This apparent contradiction is solved in section 2.2 . According to the AGLIP, IP rights only confer "the power to exclude with respect to the specific product, process, or work in question," but no substantial market power necessarily results from this ability because "there will often be sufficient actual or potential close substitutes for such product, process, or work to prevent the exercise of market power." "97 This conceptualization echoes Posner's description of markets, with differentiated products and "almost horizontal" demand curves. ${ }^{98}$ The AGLIP view, therefore, is that although the prices of intellectual goods are set above marginal cost, this deviation is usually insubstantial and therefore inconsequential for antitrust purposes.

92. Richard A. Posner, Antitrust Law 22 (2d ed. 2001). But see Klein \& Wiley, supra note 82 , at 627-28 ("[W]e disagree with the basis for this conclusion, which is the unsupported empirical assertion that these firms face 'almost horizontal' demand curves so that the monopoly power involved is 'too slight to worry about."').

93. $C f$. Reazin v. Blue Cross \& Blue Shield of Kan., Inc., 899 F.2d 951, 967 (10th Cir. 1990) ("Market power and monopoly power only differ in degree-monopoly power is commonly thought of as 'substantial' market power.").

94. AGLIP, supra note $6, \S 1.0$.

95. Id.

96. Id. $\S 2.0(\mathrm{~b})$.

97. $\quad$ Id. $\S 2.2$.

98. POSNER, supra note 92, at 22. 
However, this theory of the relations between IP and market power remains internally inconsistent. One cannot hold the view that IP laws, which prevent rapid imitation and allow prices to be maintained at higher levels, are necessary and effective, and at the same time assume that prices will not be set at that higher level because there are plenty of close substitutes. This is selfcontradictory because close substitutes, for antitrust purposes, are those goods which prevent a hypothetical monopolist from setting prices substantially above marginal cost. They must be sufficiently close so that the one good holds the seller of the other to her costs. ${ }^{99}$ Close substitutes therefore, by definition, restrain prices as imitation does. But if so, just like imitation, close substitutes must negate the incentive to innovate. If substitutes do not cause prices to fall toward marginal cost, then those substitutes are in fact not very close.

\section{B. Why the Price of Many Intellectual Goods Can Be Expected to Deviate Substantially from Marginal Cost}

Although contrary examples probably abound, for a variety of reasons that I will set forth below, we can expect the price of many intellectual goods to deviate substantially from marginal cost. This means that under the traditional definition of market power, many holders of IP rights are expected to possess market power "in the antitrust sense"-contrary to the AGLIP view. This fact, however, should be distinguished from two separate, yet not unrelated, questions. The first is what normative consequences follow a finding of market power, and the second is whether, as a matter of legal policy, courts should presume market power exists. These questions will be discussed separately below. But first, let me turn to the positive correlation between IP and market power and demonstrate why many IP holders possess market power "in the antitrust sense."

\section{The Marginal Cost of Many Intellectual Goods is Very Low}

IP law assumes that the cost of inventing or creating is often high, while the cost of reproducing the work or using the invention is often very low. ${ }^{100}$ For example, an additional copy of a feature film on VHS or DVD costs less than a dollar to produce; an additional copy of a hardcover book costs less than three dollars to manufacture; and an additional copy of many paperbacks, magazines, or sound recordings typically costs less than twenty-five cents to make. ${ }^{101}$ Many of

99. See HovenKAMP, supra note $17, \S 3.3$.

100. See, e.g., Landes \& Posner, supra note 11, at 328. A distinction should be made between the invention or work itself (the protected information) and the product that embodies that information. The marginal cost of an additional use of the information protected by the intellectual property is very low, although the marginal cost of making an additional final product that embodies the intellectual property is often (e.g., books, CDs, drug pills), but not always and not necessarily (e.g., nuclear reactors), low.

101. Peter S. Grant \& Chris WoOd, Blockbusters and Trade Wars: Popular Culture in a Globalized World 47 (2004). 
these products, however, are sold at significant price multipliers. ${ }^{102}$ Similarly, the price of many patented drugs often far exceeds production cost. ${ }^{103}$

The fact that the prices for such products often exceed marginal cost by several multipliers is not really surprising. Unless a firm faces perfect competition, which IP law often prevents, ${ }^{104}$ when its marginal cost is very low, the firm can set the price far above marginal cost even when the demand for its product is not highly inelastic. ${ }^{105}$ This means that even if the goods are only slightly differentiated, prices will be set substantially above marginal cost. This result can be easily derived from the Lerner Index, often used to quantify market power. ${ }^{106}$ The simplest formulation of the Lerner Index is $L=(P-M C) / P$ (where $P$ is the firm's price at its profit-maximizing level of output and $M C$ is the marginal cost at that level). ${ }^{107}$ The Index can have values on a spectrum from zero to one: zero in perfect competition (when $P=M C$ ) and one when $P$ approaches infinity or as marginal cost approaches zero. ${ }^{108}$ If, as in many instances involving IP, marginal cost approaches zero, the Index approaches its highest possible level. Interestingly, this happens at any price higher than zero. That is, when marginal cost approaches zero, almost any positive price will be substantially higher than the competitive level (measured by marginal cost), and any firm setting this price will be a monopolist "in the antitrust sense" - at least in the absence of an alternative definition.

In such circumstances, substitutes only set an upper limit on the profit maximizing price. Their existence determines the point above which further price increase will not be profitable, but often price at this point will be substantially above marginal cost. As long as the competitive level is understood to reflect marginal cost and market power means the ability to deviate substantially from this level, the Guideline's assertion that the "there will often be sufficient actual or close substitutes . . . to prevent the exercise of market power" is unrealistic. ${ }^{109}$

102. The phenomenon of piracy of many intellectual goods is a good indicator for the marginal cost of production. The price of the pirated good will often be very close to marginal cost.

103. Ian Ayres \& Paul Klemperer, Limiting Patentees' Market Power Without Reducing Innovation Incentives: The Perverse Benefits of Uncertainty and Non-Injunctive Remedies, 97 Mich. L. REV. 985, 1018 (1999) (citing F.M. SCHERER, INDUSTRIAL MARKET Structure And Economic Performance 454 (2d ed. 1980)).

104. IP law may enable the IP owner to prevent the making of identical copies. It does not preclude the possibility that non-infringing products will function as perfect substitutes, although the probability that such substitutes will be perfect, rather than reasonable, is low. See infra Part III.B.2. Nevertheless, contrary examples undoubtedly exist. As Jon Putnam pointed out to me in conversation, anyone can photograph a mountain and copyright her work.

105. Landes \& Posner, supra note 88, at 942-43.

106. See generally A. P. Lerner, The Concept of Monopoly and the Measurement of Monopoly Power, 1 REV. ECON. STUD. 157 (1934).

107. Id. at 169 .

108. HOVENKAMP, supra note $17, \S 3.1$ (a).

109. An interesting comparison is the merger context, wherein an ability to sustain a price increase of five percent for the foreseeable future is generally deemed by the 


\section{Pricing Intellectual Goods at Marginal Cost Is Not a Viable Strategy}

Not only can producers of intellectual goods set price substantially above marginal cost, they must do so. The standard cost pattern of many IP goods often requires large sunk investment but a negligible marginal cost. Under such conditions, setting the firm's prices at marginal cost will necessarily condemn it to losses. ${ }^{110}$ This result follows because the firm's total revenue (its marginal cost times output) is necessarily lower than its total cost. ${ }^{111}$ Facing such a cost structure, no firm will enter the market in the first place unless it can expect to set prices high enough above marginal cost to cover its sunk cost. ${ }^{112}$

But a firm contemplating entry must also consider the possibility that post-entry competitors who do not have to bear the sunk cost will copy or imitate its goods, forcing prices down toward marginal cost. IP law, which prevents this type of direct competition, at least for a period of time, usually addresses this concern. ${ }^{113}$ However, the firm must also consider the possibility of competitive entry by less direct copiers or imitators, a concern to which IP law provides only partial solutions. In patent law, for example, "[t]he doctrine of equivalents prevents an accused infringer from avoiding liability for infringement by changing only minor or insubstantial details of a claimed invention while retaining the invention's essential identity." 114 In copyright law, two works may not be literally identical and yet, for purposes of copyright infringement, they may be found substantially similar. ${ }^{115}$ Thus, to avoid liability, a competitor must differentiate herself from the protected good. So the broader the scope of an IP right, the more differentiated other non-infringing substitutes must be and the greater the market power conferred upon its holder. ${ }^{116}$

But relying on IP law-unless extremely broad in scope - only partially solves the potential innovator's problem. Theoretically, two sellers can offer two functionally equivalent products that substitute for each other perfectly or almost perfectly even though they utilize completely different technologies. In this case,

U.S. antitrust authorities to be indicative of market power. See U.S. DEP'T OF JUSTICE \& FED. TRADE COMM'N, supra note $85, \S 1.11$.

110. William J. Baumol \& Daniel G. Swanson, The New Economy and Ubiquitous Competitive Price Discrimination: Identifying Defensible Criteria of Market Power, 70 ANTITRUST L.J. 661, 668 (2003).

111. Id.

112. Id. at 671

113. In some cases, the sole fact of being the first entrant in a new market can give a large enough advantage so that the sunk cost of developing the new product can be recovered even in the absence of actual or effective IP protection. See, e.g., LANDES \& POSNER, supra note 13, at 40.

114. Festo Corp. v. Shoketsu Kinzoku Kogyo Kabushiki Co., 234 F.3d 558, 564 (Fed. Cir. 2000) (citing Graver Tank \& Mfg. Co. v. Linde Air Prods. Co., 339 U.S. 605, 608 (1950)).

115. Melville B. Nimmer \& DAVid Nimmer, Nimmer on COPYRight, Release 63 $\S 13.03[\mathrm{~A}]$ (2004).

116. See, e.g., Richard Gilbert \& Carl Shapiro, Optimal Patent Length and Breadth, 21 RAND J. ECON. 106, 107 (1990). 
even with very broad IP rights, price could drop rapidly to marginal cost. ${ }^{117}$ In addition, an innovator contemplating entry must anticipate an even worse scenario: the post-entry introduction of a non-infringing product that is sufficiently superior to her own that will totally displace it rather than merely compete with it. ${ }^{118}$ IP laws, of course, afford no protection against such risks.

A related but different risk stems from the fact that a significant portion of the costs of creation are incurred well before an innovator knows whether a product will be introduced and what the demand for that product will be. As Jorde and Teece describe it, innovation is "a collective social process involving risktaking and uncertainty, probing, reprobing, experimenting, and testing. 'Dry holes' and 'blind alleys' are the rule and not the exception." 119 Similarly, in the creative industries, such as films, literature, and music, while there might be less certainty that a product will be produced, there is complete uncertainty about whether it is going to be a commercial success or a flop; demand can only be discovered through direct experience, ${ }^{120}$ and it is often the case that the actual principle to predict demand equates to "nobody knows anything."121 This line of thought implies that in order to be viable, an investment would not be made unless the expected profits in case of success are high enough to compensate for the risk of failure. ${ }^{122}$ The observed profits of the winner (i.e., the markup above cost) therefore should necessarily be high.

Roberts and Putnam give two illustrative examples. In the first, two firms each invest $\$ 100$ on research and development in period one. In period two, the winner earns $\$ 250$ while the loser earns $\$ 0$, with probability of 0.5 to win (that is, to develop a commercial product). Ex ante each firm's expected rate of return is $25 \%$. However, ex post the winner's observed rate of return is $150 \%$. $^{123}$ If market

117. The magnitude of this risk largely depends on the relevant technology. In technological innovations, the number of known ways to efficiently reach a certain result is finite (e.g., the number of methods to synthesize a certain compound is limited). In creative and cultural works, while the number of ways to express an idea could be thought of as approaching infinity, the mode of consumption dictates that two different works will only rarely be perfect substitutes. Consumers often have strong preferences for one product over another, even if the two are equivalent in their objective functionality, broadly defined.

118. Frank R. Lichtenberg \& Tomas J. Philipson, The Dual Effects of Intellectual Property Regulations: Within-and Between-Patent Competition in the U.S. Pharmaceuticals Industry, 45 J.L. \& ECON. 643, 646-47 (2002) (estimating that betweenpatent competition, most of which occurs while a drug is under patent, costs the innovator at least as much as within-patent competition, which cannot occur until the drug is off patent).

119. Thomas M. Jorde \& David J. Teece, Rule of Reason Analysis of Horizontal Arrangements: Agreements Designed to Advance Innovation and Commercialize Technology, 61 ANTITRUst L.J. 579, 581 (1993).

120. Arthur De Vany \& Ross D. Eckert, Motion Picture Antitrust: The Paramount Cases Revisited, 14 RES. L. \& ECON. 51, 55 (1991).

121. Id. at 55 n.8 (citing William Goldman, AdVENTURES In the ScReEn TRADE: A Personal View of Hollywood and Screenwriting 39 (1983) ("Nobody Knows Anything" is "the single most important fact of the entire movie industry.")).

122. Landes \& Posner, supra note 11, at 328-29.

123. Gary L. Roberts \& Jonathan D. Putnam, Allegations of Harmony Between IP and Competition Policies: In Search of the Lost Chord, in 1999 Annual Fall Conference 
power is measured by the deviation of price from marginal cost, then the winner has substantial market power; yet if the cost of capital is $25 \%$, then in expectation the firm will just break even. ${ }^{124}$ In the second example, the firms invest the same amount (\$100 each) and have the same probability of developing a commercial product $(0.5)$. If only one is successful, it gets $\$ 300$, and if both succeed each gets $\$ 200$; if neither is able to develop a product, both get zero. If there is only one winner, its rate of return is $200 \%$, but even in the case when both firms develop competing but differentiated products, the observed rate of return is still $100 \%$, despite the fact that the expected rate of return remains $25 \%{ }^{125}$

Applying the standard definition of market power to these examples suggests that successful innovators are likely to be found to possess significant market power. Such a finding could of course be highly attractive for antitrust plaintiffs if it leads to antitrust liability and a resulting reduction of prices. However, if as a result firms anticipate price reductions such that the expected rate of return is below the cost of capital, then they will prefer to seek alternative investment options. ${ }^{126}$ This possibility, which may have a deleterious effect on the incentive to invest in innovation, implies that we should be cautious about condemning successful IP owners exercising market power by pricing at substantial deviation from marginal cost but whose expected rate of return is normal. However, this concern should be discussed when dealing with the normative consequences of the existence of market power. It should not be confused with the positive fact that innovators who succeed in bringing to the market valuable intellectual goods often set their prices substantially above marginal cost.

\section{C. “A Presumption of Market Power Has No Empirical Basis"}

Perhaps the AGLIP and their allies do not try to say anything about the economic connection between IP and market power and only argue that there is no place for a legal presumption of market power because IP rights do not necessarily confer market power. Perhaps they only take the position that because there could be close substitutes, market power must be proven empirically rather than presumed. In fact, this is my reading of the statements in Walker Process and Jefferson Parish, two earlier cases in which the presumption of market power was eroded. ${ }^{127}$ In Walker Process the Court stated that "[i]t may be that the [patented] device . . . does not comprise a relevant market," 128 and "[t]here may be effective substitutes for the device which do not infringe the patent." ${ }^{29}$ Similarly in Jefferson Parish, Justice O'Connor opined that "a patent holder has no market power in any relevant sense if there are close substitutes for the patented

ON COMPETITION LAW 311, 321 (Glenn F. Leslie ed., 2000) (the expected rate of return is $25 \%([0.5 \times \$ 0+0.5 \times \$ 250] / 100-1))$.

124. Id.

125. Id. at $321-22([0.5 \times \$ 0+0.25 \times \$ 200+0.25 \times \$ 300] / 100-1)$.

126. See id.

127. See supra Part I.C.

128. Walker Process Equip., Inc. v. Food Mach. \& Chem. Corp., 382 U.S. 172, 177-78 (1965) (emphasis added).

129. Id. at 178 (emphasis added). 
product." 130 The Supreme Court used similar language in ITW when it stated that "a patent does not necessarily confer market power . . . and therefore [we] hold that . . . the plaintiff must prove that the defendant has market power . . .."131 If that were truly the case, the view that market power should not be presumed could be justified on grounds of judicial policy, for example, to discourage nuisance litigation motivated by the lure of potential treble damages. ${ }^{132}$

But the AGLIP, which clearly influenced the ITW Court, go much further than rejecting a presumption of market power on such grounds. ${ }^{133}$ The AGLIP do not merely suggest that there may be close substitutes to prevent the exercise of market power; they suggest that there often will be close substitutes preventing the exercise of market power. ${ }^{134}$ Sure enough, the word "often" could be just another example of ambiguity in the AGLIP. The word covers a range of probabilities, so it is not entirely clear whether "often" in this context means only that the number of cases in which IP rights do not confer market power is not insignificant, or whether "often" means that in the majority of cases IP rights do not confer market power. Yet, when read in conjunction with the AGLIP first principle- that for the purpose of antitrust analysis, IP rights are "essentially comparable to any other form of property" 135 - the theory that emerges holds that until the contrary is proven, any antitrust analysis - whether it involves intellectual goods or notshould assume that there are plenty of substitutes, and prices are therefore expected to be set not far from marginal cost.

\section{Intellectual Property Is Just Like Any Other Type of Property}

The AGLIP analogy between IP and other types of property, in my view, creates an anti-presumption, or a presumption that IP rights do not confer market power, going beyond a simple demand that market power be proved. Further, the AGLIP have not been alone in invoking this analogy. For example, Areeda and Hovenkamp use it to express their view in favor of an anti-presumption much more explicitly. They explain:

a patent is presumptively not a monopoly at all, but merely the right to exclude others from copying a particular process or product. As such it is no different than any other property right-for example,

130. Jefferson Parish Hosp. Dist. No. 2 v. Hyde, 466 U.S. 2, 38 n.7 (1984) (O'Connor, J., concurring) (emphasis added), abrogated by Ill. Tool Works Inc. v. Indep. Ink, Inc. (ITW), 547 U.S. 28, 31 (2006).

131. ITW, 547 U.S. at 45-46 (emphasis added).

132. William Montgomery, Note, The Presumption of Economic Power for Patented and Copyrighted Products in Tying Arrangements, 85 CoLuM. L. REV. 1140, 1151 (1985). In Walker Process, in fact, treble damages were the remedy sought by Walker Process in its antitrust counterclaim. 382 U.S. at 173.

133. AGLIP, supra note $6, \S 2.2$. Clearly, the argument about nuisance litigation motivated by potential treble damages is largely inapplicable to the antitrust agencies, which cannot seek this remedy in their enforcement activities except in the rare occasions when the U.S. Government itself suffers injury as a result of an antitrust violation. See HOVENKAMP, supra note $17, \S 15.1(\mathrm{~b})$.

134. AGLIP, supra note $6, \S 2.2$.

135. Id. $\S 2.0(\mathrm{a})$. 
ownership of an airplane or pipeline entails the right to exclude others from using them. Thus the patent infringement action is nothing more than a variation on the common law trespass action. Neither ownership of the property right nor the power to exclude conveys monopoly power unless the property right in question dominates a properly defined relevant market. The great majority of patents do not. ${ }^{136}$

While I agree that the existence or lack of market power in each specific case is a matter of fact, and therefore cannot be simply and conclusively presumed, I strongly disagree with the opposite presumption that the relationship between IP and market power essentially mimics the relationship between any other form of property and market power. If this is the AGLIP and their intellectual allies' view of the relationship between IP rights, prices, and marginal cost (and even if it is not, there is always a possibility that people who rely on the AGLIP interpret them in that fashion), it is inaccurate and misleading. As such, it might lead to erroneous decisions by those who adhere to or rely on this view.

But the relationship between IP and market power differs from the relationship between tangible property and market power. With tangible assets, scarcity is a given. The assets are rivalrous in consumption (which means that they cannot be simultaneously used without being depleted). Therefore, the level of output that can be derived from them is finite. The grant of property rights in such assets determines who is entitled to the output that can be derived from those assets, but it does not determine the quantity of that output. ${ }^{137}$ If the owner of the asset has market power and therefore is able to control the level of price and output, it is a result of factors exogenous to ownership. Depriving the owner of her property rights in the asset and moving it to a regime of common ownership would not affect scarcity (and may actually result in lower output in the longer run as a result of overuse: the famous "tragedy of the commons"). ${ }^{138}$ Therefore, it is fair to reject any general connection between property rights in tangible assets and market power. In contrast, IP rights are directly designed to affect the price and output of intellectual assets. "It is a conscious decision to create scarcity in a type of good in which it is ordinarily absent in order to artificially boost the economic returns to

136. 3 Philip E. Areeda \& Herbert Hovenkamp, Antitrust Law: An Analysis of Antitrust Principles AND Their ApPlication \ 704a (2d ed. 2002); see also Frank H. Easterbrook, Intellectual Property is Still Property, 13 HARV. J.L. \& PUB. POL’y 108, 109 (1990). Judge Easterbrook states:

Patents give a right to exclude, just as the law of trespass does with real property. Intellectual property is intangible, but the right to exclude is no different in principle from General Motors' right to exclude Ford from using its assembly line, or an apple grower's right to its own crop. Easterbrook, supra, at 109.

137. See PlANT, supra note 13, at 36 (noting that with regard to tangible property, "[n] either the withholding, nor the disposal of the property of any one owner will in general affect appreciably the price of the commodity in question").

138. E.g., Garrett Hardin, The Tragedy of the Commons, 162 SCI. 1243, 1244 (1968). 
innovation." 139 There is no guarantee that this intended result would follow. But when it is achieved, market power and the grant of IP rights inherently connect. The grant of an IP right is often the sine qua non for its owners' ability to exercise market power.

If any analogy is useful in this context, ${ }^{140}$ it is not an analogy to the ownership of an airplane or a pipeline, as Areeda and Hovenkamp suggest, but rather to a governmental grant of an exclusive franchise to operate an airline between two destinations or to run the only pipeline between two regions, accompanied by a rule that makes it illegal for others to offer the same air service or lay additional pipelines. Clearly, just as with IP rights, such an exclusive franchise does not necessarily mean that the franchisee is a monopolist, nor does the franchise guarantee commercial success. It may turn out that such exclusive franchises are not worth much. There might be other equally efficient means of transportation between the two destinations or other methods to deliver liquids or gas between the regions, which are good enough substitutes to the specific airline or pipeline - and even monopolists may go bankrupt. Yet it does not seem unreasonable to expect that if such an exclusive franchise exists (and is lobbied for), it might result in significant market power. Therefore, the relationship between IP and market power are more than coincident. Market power is the intended result of IP.

\section{Most Intellectual Property Rights Have No Commercial Value}

One of the strongest arguments against the presumption of market power is based on the empirical finding that most IP rights have no commercial value: If most IP rights have no commercial value, a fortiori they lack market power. ${ }^{141}$ Such empirical findings ${ }^{142}$ may seem inconsistent with the previous prediction that facing the risks of innovation, those who finance it would tend to direct their efforts toward the creation of intellectual goods difficult to substitute and garnering enough market power to cover the risk-adjusted cost of innovation. But there is no real inconsistency. First, innovators may seek to create non-

139. Mark A. Lemley, Property, Intellectual Property, and Free Riding, 83 TEX. L. REV. 1031, 1055 (2005) (emphasis added).

140. Id. at 1075 (arguing that the needs and characteristics of intellectual goods and IP rights are unique and require their own analysis, not analyses borrowed from other areas).

141. See, e.g., HovenKAMP, supra note 17, § 3.9(d).

142. See, e.g., Phillip Areeda \& Louis Kaplow, Antitrust Analysis: Problems, Text, AND CASES 441 n.49 (1988) (noting that between eighty and ninety percent of all patents may have no commercial value (citing SUBCOMM. ON PATENTS, Trademarks and Copyrights of the S. Comm. ON THE Judiciary, 85Th Cong., AN ECONOMic Review of THE PAtent System 12 (Comm. Print 1958) (primarily authored by Fritz Machlup)); F.M. Scherer, in Salem M. Katsh, Jack E. Brown \& F.M. Scherer, Panel Discussion, The Value of Patents and Other Legally Protected Commercial Rights, 53 ANTITRUST L.J. 535, 547 (1985) ("Statistical studies suggest that the vast majority of all patents confer very little monopoly power-at least, they are not very profitable."). For more precise estimates of the value of patent rights, see Mark Schankerman \& Ariel Pakes, Estimates of the Value of Patent Rights in European Countries During the Post-1950 Period, 96 ECON. J. 1052 (1986). 
substitutable works, but there is no guarantee of success. Second, the law's requirements for IP protection are independent of commercial success-both successful and unsuccessful endeavors may result in protected intellectual goods. In addition, the thresholds for obtaining IP protection are sometimes very low: "virtually any combination of words, sounds, or images can be copyrighted."143 Similarly, it does not require much to satisfy the novelty, usefulness, and nonobviousness requirements for patentability. ${ }^{144}$ Nevertheless, the satisfaction of these requirements does not mean that the work in question will garner commercial value, not to mention market power. ${ }^{145}$ Furthermore, the period of commercial success, even when an intellectual good musters it, may not be commensurate with the term of IP protection; it may be much shorter. Consequently, the fact that most patents or copyrighted works have no commercial value (and therefore no market power) should not be surprising.

But when considering whether there should be a presumption of market power, looking at all intellectual goods as the relevant sample can be highly misleading. First, antitrust analysis, focused on restraints on trade, is likely to be interested only in those intellectual goods that have commercial value and are involved in trade. The number of intellectual goods that have no commercial value and are not involved in trade tells us very little about the prices and price-cost ratios of those that do. If we narrow our observation to the subset of those intellectual goods that $d o$ have commercial value, assuming even distribution along a spectrum according to the level of available substitutes (and the associated degree of market power) and that marginal cost is very low, as is often the case, we can expect, applying the Lerner index, that the average "successful" intellectual good not only will not be priced at marginal cost, but will actually be priced substantially above it as we have previously observed. ${ }^{146}$

Moreover, because the presumption of market power is a legal concept, it will always be invoked or rejected in the context of an actual legal dispute between an IP holder and her competitor, customer, or supplier (or an antitrust agency by extension). Any discussion of whether IP holders should be presumed to have market power outside the context of such disputes is inconsequential, at least for antitrust purposes. Therefore, the relevant sample for assessing the merit of the presumption could be narrowed even further to the subset of the IP rights whose existence or exercise is disputed and litigated. For reasons outlined below, those legal disputes would concentrate on intellectual goods high in commercial value, likely without many close substitutes.

\section{Choosing the Correct Sample: Disputes Involving Intellectual Property Rights and Market Power}

Even if, as a matter of sheer numbers, most intellectual goods have enough close substitutes to prevent the exercise of market power, one could predict that disputes would develop and litigation would concentrate on the more valuable

\footnotetext{
143. AREEDA \& HovENKAMP, supra note 68, at 137.

144. Id. at 138 .

145. Id.

146. See supra Part III.B.1.
} 
among them. That is, litigation would focus on the intellectual goods that confer greater market power upon their owners. ${ }^{147}$

Litigation involving IP can be characterized as belonging to one of two types: horizontal or vertical. A horizontal dispute occurs in a market where both parties are actual or potential competitors, where the plaintiff typically seeks "to impair the defendant's performance in their shared market or even to exclude the defendant from the market completely." "148 In a vertical dispute, the parties are not competitors and the plaintiff's purpose is to seek settlement payments from the downstream defendant who uses the intellectual good. ${ }^{149}$

One of the factors that determine whether a dispute will arise and litigation ensue is the size of the stakes involved. ${ }^{150}$ A holder of an IP right would not attempt to exclude a competitor unless the expected gains from such exclusion outweigh the cost of litigation. Because IP litigation, especially involving patents, is often extremely costly ${ }^{151}$ and may sometimes also expose the patent to the risk of invalidity, the expected gains from such an attempt to exclude must be substantial. Yet, if the market is highly competitive because the technology has many close substitutes, then the plaintiff will gain very little, if anything, from the exclusion of a competitor. Any output reduction and price increase resulting from the exclusion of that infringing defendant will be rapidly offset when other noninfringing competitors expand their output. ${ }^{152}$ Therefore, assuming IP holders act

147. Scherer, supra note 142, at 547. This prediction has been confirmed empirically. See, e.g., Brief of Professor F.M. Scherer as Amicus Curiae in Support of Respondent at 5, Ill. Tool Works Inc. v. Indep. Ink, Inc. (ITW), 547 U.S. 28 (2006) (No. 041329), 2005 WL 2427642; Jean O. Lanjouw \& Mark Schankerman, Characteristics of Patent Litigation: A Window on Competition, 32 RAND J. ECON. 129, 147 (2001).

148. Michael J. Meurer, Controlling Opportunistic and Anticompetitive Intellectual Property Litigation, 44 B.C. L. REV. 509, 512 (2003).

149. Id. The distinction between the horizontal case and the vertical case is nevertheless fuzzy. Even in a horizontal dispute, the plaintiff is claiming control over one of the defendant's inputs, so in that sense it is also a vertical dispute. Similarly, the distinction largely depends on the validity of the infringement claim. Even in the vertical case, if the claim is invalid, the defendant can often produce the input independently (due to the nonrivalrous nature of the intellectual good) and in this sense could be seen as a competitor in the upstream input market. The distinction between the plaintiff's purposes may not be clear either. A plaintiff may seek settlement payments but use the threat of exclusion in order to improve her bargaining position toward such settlement.

150. Lanjouw \& Schankerman, supra note 147, at 132.

151. See National ACAdEMy OF Sciences, A Patent System for the 21st Century 38 (Stephen A. Merrill et al. eds., 2004). The authors state:

The median cost to each party of proceeding through a patent infringement suit to a verdict at trial is at least $\$ 500,000$ where the stakes are relatively modest. Where more than $\$ 25$ million is at risk in a patent suit, the median litigation cost is $\$ 4$ million for each party. ...

Id.

152. In fact, this is the flipside of the usual skepticism in antitrust toward predatory pricing claims. In predatory pricing litigation, the plaintiff asks the court to infer an exclusionary outcome from the defendant's conduct, and courts usually require a showing of market power, likelihood of exclusion, and likelihood of recoupment because otherwise the alleged predation is inconsistent with rational behavior. See, e.g., Cargill, Inc. 
rationally, horizontal disputes are more likely when market power exists and its maintenance is sought. ${ }^{153}$

In some cases, nonetheless, an IP holder may sue her competitor only to increase her sales at the expense of the excluded competitor, even if the market is competitive. In such cases, the market share of the excluded competitor will be divided among the remaining competitors. Each of them would gain, but the level of output and prices in the market would not necessarily change. In other words, a competitor would be excluded, but competition not necessarily harmed. However, the larger the number of competitors and the smaller the market share of the plaintiff, the lower are the expected benefits to the plaintiff, who therefore, given the cost of litigation, will be less likely to embark on the exclusionary operation. This implies that even these suits are more likely to be brought in markets with a small number of competitors and by the larger among them. In such circumstances, the exclusion of one competitor will not simply lead to reallocation of market shares, but also to lower output and higher prices. In other words, the exclusion of one competitor will lead to an increase in the plaintiff's market power.

Vertical conflicts follow a similar logic. If an IP right is used as an input to produce another product, but it is just as good a substitute as many other potential inputs (whether protected by IP or not), then the available gains may not justify the cost of litigation. The IP holder cannot expect to receive high royalties in a settlement because the user has competitive alternatives. The user cannot expect to save much from pursuing his costly defense and instead will switch to other alternatives. Therefore, both parties have strong incentives to avoid litigation or to settle it at an early stage. The opposite holds if the IP holder possesses market power. In this case, the plaintiff can expect to receive high royalties, and the user can save the same amount by proving that the IP right is invalid or not infringed. The stakes are high, and both parties have good reasons to finance the costly litigation. $^{154}$

v. Monfort of Colo., Inc., 479 U.S. 104, 119 n.15 (1986). In the case of horizontal IP disputes, the intent to keep prices high and the exclusionary purpose and outcome are overt; this is the remedy sought by the IP owner, and therefore rationality implies that the IP owner has market power and new entrants into the market are unlikely.

153. It should be noted however that some IP owners, owning a portfolio of IP rights, may initiate some weak infringement suits even when they will gain nothing in the particular case in an attempt to build reputation as aggressive IP holders, a reputation that will help them prevent entry into those markets in which they do possess market power. See Trebilcock et al., The Law and ECONOMics of CANAdian Competition Policy 297 (2002) (explaining the impact of an aggressive reputation in the case of predatory pricing).

154. Of course, this does not mean that any IP right that is litigated should necessarily involve market power, because opportunistic litigation can be pursued even in a case where the IP in question does not confer market power but the party who is utilizing this IP has made significant specific investment in its utilization. For example, if a producer has already produced a film based on another writer's script without clearing copyright issues in advance, she cannot substitute other scripts for it and may find herself ending up paying high royalties if the film is successful, even if prior to the commencement of the production there were many more substitutes that could have been properly licensed for a lower price. Professional users of IP may expect this outcome and try to clear all IP issues before making irrecoverable investments in utilizing other peoples' IP, but this may not 
In sum, while not every dispute that involves intellectual goods necessarily implies the existence of market power, a significant number of them probably do. However, an important caveat should accompany this conclusion. Although it seems probable that IP disputes often involve market power, the correctness of this observation is not independent from the existence or absence of a presumption of market power. If a presumption exists, the burden on plaintiffs challenging IP holders is lower and more cases are litigated. Thus, on average, defending IP holders will have less market power. The resulting decrease in defendants' average market power may undermine the empirical validity of the presumption and consequently courts' willingness to resort to it. As a result, the burden on plaintiffs may increase and the sample of litigated cases might shrink. On average, however, this would lead to an increase in the amount of market power held by IP defendants and so on. This dynamic does not change the fact that those IP rights with no commercial value at all are unlikely to be part of the sample, although it may explain why courts' willingness to presume market power may change over time.

\section{E. Intellectual Property Rights: Market Power or Rents?}

A different argument in the debate on IP and market power has been launched by Edmund Kitch ${ }^{155}$ and Kenneth Dam. ${ }^{156}$ Both have argued that the use of the term "monopoly" in the IP context is incorrect because the right to exclude, granted by a patent (and possibly other IP rights), ${ }^{157}$ is equivalent to any other property right and may only give rise to economic rents rather than any significant market power. ${ }^{158}$ According to Kitch,

[t] he basic distinction . . . is between a right which confers a comparative advantage in production which is sold into a market where the demand curve facing the firm has a slope of zero, and a

always be possible. Contracts may be incomplete, so we can expect to see attempts to renegotiate ex post. In some cases, contracts may not be reached at all: the IP holder may be unknown or could be too costly to locate, or the user may believe that her use of the IP is not infringing. Yet even then, the abundance of potential substitutes ex ante will supply courts with a benchmark for the appropriate compensation ex post, which in a competitive environment would be relatively low, and as in the previous case, the expected gains from such litigation may not justify the cost of litigation. The issue gets more complicated in purely opportunistic lawsuits that for a variety of reasons, such as avoidance of the cost of litigation and the uncertainty about the exact scope of the disputed IP rights, may result in settlement payments even if the IP rights allegedly infringed have no commercial value. See Meurer, supra note 148, at 513-24. Opportunistic litigation (and resulting settlement) may also be encouraged by the remedies available to plaintiffs, such as, in the case of U.S. copyright law, statutory damages and infringer's profits, 17 U.S.C. $\S 504(a)$, (c) (2006), or treble damages in U.S. patent law, 35 U.S.C. $\$ 284$ (2006).

155. Edmund W. Kitch, Patents: Monopolies or Property Rights?, 8 RES. L. \& ECON. 31 (1986).

156. Kenneth W. Dam, The Economic Underpinnings of Patent Law, 23 J. LEGAL STUD. 247 (1994).

157. The papers by Kitch and Dam discuss patents, not IP rights generally.

158. See Dam, supra note 156, at 250-51; Kitch, supra note 155, at 38, 47. 
right which confers the advantage of being able to sell into a market where the demand curve facing the firm has a negative slope. ${ }^{159}$

While a right of the second type confers market power (and could be adequately termed "monopoly"), a right of the first type is just an economic rent. According to Dam, using the term "rent" rather than "monopoly" is preferable because unlike monopolies, which are rare:

Economic rents are common in the economy. They are enjoyed wherever an economic actor has a cost advantage that competitors cannot match, for legal or other reasons. A legal reason might be some form of regulatory constraint or a subsidy, stemming, for example, from some form of industrial policy. But rents may arise from more natural causes. The advantage of superior location is a common example in real estate. Superior talent in the arts and professional sports is another. ${ }^{160}$

Kitch and Dam both argue that patents only give their owners, who produce products sold in competitive markets, a cost advantage over competitors that allows them to make more money, but the level of output in the product market will either remain the same compared to the pre-patent situation or increase. ${ }^{161}$ In any event, the argument goes, granting the patent will not result in lower output and higher prices in the product market. Therefore, the common concerns about monopoly-lower output and higher prices - cannot be attributed to patents. ${ }^{162}$

Before discussing this argument, it is useful to briefly define "rents." The term "rent" generally refers to "the return earned by a factor in excess of the minimum return necessary to attract the factor to a particular market or to induce the factor to remain in the market."163 Economists, however, distinguish between different types of rents. ${ }^{164}$ Kitch's and Dam's arguments refer to "Ricardian rents," which are indeed common in competitive markets. Ricardian rents constitute "the income derived by owners of inframarginal factors of production available in limited amounts." 165 When marginal cost is increasing and market equilibrium price is set at marginal cost, the last firm - the marginal-just breaks even, whereas all other firms - the inframarginal, whose marginal cost is lower - earn Ricardian rents. ${ }^{166}$ However, when production requires specific investment, the

159. Kitch, supra note 155, at 47. Kitch's argument assumes that most patents do not cover actual final products, but rather technologies that reduce the cost of making another product sold downstream in a competitive market. Id. However, no reference is given to substantiate this empirical assumption.

160. Dam, supra note 156, at 250.

161. Dam, supra note 156, at 250-51; Kitch, supra note 155, at 34 .

162. See Dam, supra note 156, at 250-51.

163. TREBILCOCK ET AL., supra note 153, at 55.

164. Id.; see also Margaret Sanderson \& Ralph A. Winter, "Profits" versus "Rents" in Antitrust Analysis: An Application to the Canadian Waste Services Merger, 70 ANTITRUST L.J. 485, 494-502 (2002).

165. TREBILCOCK ET AL., supra note 153, at 54.

166. Id. 
return necessary to attract such investment will not be considered a true rent but rather a quasi-rent. ${ }^{167}$

Two essential elements underlie Kitch's and Dam's arguments. One is an empirical assumption that most IP rights cover internal processes in the making of a final product, rather than final products themselves. ${ }^{168}$ The second element- the argument's essence - is theoretical: patents at most give rise to a competitive advantage resulting in Ricardian rents, but not in market power. ${ }^{169}$

Yet, Kitch's and Dam's arguments suffer from several difficulties stemming from a failure to recognize that the scarcity of the relevant factor of production gives rise to Ricardian rents in the case of ordinary inputs, whereas any cost advantage that results from knowledge does not face the same scarcity limitation. This point carries several implications. First, if constant or increasing returns to scale exist, the cost advantage of the technology can be so substantial that the firm with the exclusive right to use the technology can "compete away" any other competitor and gain a monopoly in the final product. ${ }^{170}$ Even if there are diseconomies of scale preventing that firm from effectively serving the entire market, it may still capture a large share of it and exercise some market power over the final product, which, depending on the elasticity of demand and the size of the market, may result in more or less significant deadweight loss. ${ }^{171}$ It is true that if the patented technology reduces the cost of production, then the total output in the market for the final product may expand beyond the pre-invention level, ${ }^{172}$ but this does not turn the market into a competitive one.

Second, patents and other IP rights clearly cover both final products and services and technologies to produce other products and services, and when such differences are relevant, it is surely helpful to acknowledge them. Yet it is not clear that this distinction is useful in the current debate because a patented technology that improves the production of, say, a widget, can often be licensed to other producers of widgets, and sometimes to manufacturers of gadgets, too. Hence, at

167. Id. at 55 .

168. Kitch, supra note 155 , at 39. Although Kitch acknowledges that sometimes patents, such as drug patents, do cover final products and that some of them "that achieved dramatic and unique reduction in the cost and [increased] effectiveness of medical care probably have conferred monopolies upon their owners," he suggests that these are very exceptional cases. $I d$. Dam argues that patents rarely confer market power, even when they do cover final products. Dam, supra note 156, at 249-50. Dam states:

[W]ithout the benefit of empirical research, it is entirely plausible to conclude that in the great bulk of instances no significant market power is granted. We must bear in mind that leading companies may obtain 1,000 or more patents in a single year, and yet many such firms are

Id. unlikely ever to obtain even a single monopoly in any market.

169. See Dam, supra note 156, at 250-51; Kitch, supra note 155, at 38, 47.

170. In essence, the exclusive right in such cases turns the firm into a natural monopoly. See generally Richard A. Posner, Natural Monopoly and Its Regulation, 21 STAN. L. REV. 548, 548 (1969).

171. Landes \& Posner, supra note 88, at 953-56.

172. Dam, supra note 156, at 251. 
least two markets can be affected by the patent: the market for widgets and the market for the technology. Therefore, while a vertically integrated patent holdermanufacturer may face a horizontal demand curve in the market for widgets, the same firm acts, at least potentially, in the technology market where it faces a down-sloping demand curve. ${ }^{173}$ Of course, the patent holder will not necessarily have market power in the market for the technology. Several substitute technologies for making widgets or gadgets could exist, and if such substitutes are perfect, no market power would exist. But in such a case, the technology would hardly yield any Ricardian rents in the final product market because the competitors who do not have access to the patented technology could use any of the other technologies instead. In this case, the market price of the final product will fall and all the rents dissipate.

Third, the fact that any patented technology could be licensed reveals the fundamental difficulty with the patent qua rent argument. Dam notes that rents can arise for a variety of legal reasons, such as regulatory constraint or subsidy or from more natural causes such as superior location or superior talent. ${ }^{174}$ Although all types of rents provide some firms cost advantages competitors cannot match, there are substantial differences between different sources of rents. The distinction between rivalrous and non-rivalrous goods or resources is useful in this context. Take for example the rent created by superior location in real estate markets. ${ }^{175}$ This is an example of a rivalrous resource: other sellers in this real estate market cannot share this location and the advantage that it confers. So are other sources of rents such as a manufacturing location in proximity to the markets (which reduces delivery costs), a nearby waterfall that can provide cheap energy (when competitors, located elsewhere, have to pay the full market price for their energy inputs), material created as a byproduct in the manufacture of another product (when competitors have to purchase this input), etc. Whether the rent's source is rivalrous or non-rivalrous may critically affect the level of output and price in the market for the final product - the question that market power is all about. If a rivalrous resource confers a rent on a firm in a perfectly competitive market, the rent will increase the profit of that firm but will not affect the level of output and price in the market. ${ }^{176}$ The firm has no power to affect the total output and price in the market, and can only produce a given amount. The only difference between that firm and its competitors is that the firm earns Ricardian rents.

When the rent is a result of a rivalrous resource, there will generally be no serious policy concerns with an exclusive possession of that resource by one firm. Because the resource is rivalrous, only a finite level of benefit can be derived from it. Important policy considerations, such as the expectation that exclusivity will lead to optimal use of the resource by increasing the likelihood that it will be

173. The phenomenon of patent boutiques, firms whose entire business consists of licensing patented products or processes and that are not vertically integrated into manufacturing, is a good example indicating that such markets exist.

174. Dam, supra note 156, at 250.

175. See, e.g., id.

176. I assume here that the benefits available from that good are fully consumed and that there are decreasing returns to scale so that the output produced utilizing the advantageous good is too small to affect the total output in the market. 
possessed by those who value it most, support allowing only one person to possess the good.

In contrast, when the rent results from one firm's possession of a resource not inherently rivalrous, but one that becomes non-rivalrous only as a consequence of IP law, the firm's right to exclude others from using this resource could directly affect output and prices in the market and should lead to more complex policy considerations. Had this non-rivalrous resource, an invention for example, not been patented and its use by all producers been open to all, as Dam correctly concedes, "all producers would gain the same cost advantage and the economic rent would be competed away; production would rise as cost fell . . . ."177 If, however, IP laws allow the firm to exclude others from using this resource, as they do, then the firm who owns it can effectively restrict production and increase price in the market for the final product. Now, ordinarily, when a firm has the power to control the level of output and price in a market, we would usually say the firm has market power. ${ }^{178}$ Dam does not dispute this. He acknowledges that "in that sense one could say that the patent restricts production and causes a deadweight loss" yet argues that "even in this . . . case we can discern that the term 'monopoly' does not add to our understanding." 179 However, according to Dam, the reason the term monopoly does not add to our understanding is that we are all better off with patents than without them for all the ordinary reasons (i.e., the benefit of innovation and the assumption that absent patent protection there would not be incentive to invent or incentive to disclose inventions, etc.). ${ }^{180}$ Yet replacing the term monopoly with the term rent adds even less to our understanding. The term rent does not distinguish between inherently rivalrous resources and resources that only become rivalrous because IP laws prevent others from using them. Therefore, using the term to describe both contexts in which no market power and no policy trade-offs are required, as well contexts of IP where market power could exist and more complex policy trade-offs are required, leads to vagueness rather than clarity. Additionally, Dam's tautological suggestion to "restrict the concept of monopoly to circumstances where the patents are used as a device to mask what one would otherwise call a monopoly"181 is extremely unhelpful.

Using the terminology of rents, one could argue that because returns in excess of marginal cost are necessary to attract investment in intellectual goods, such returns should only be viewed as quasi-rents. But this insight, too, does not necessarily lead to greater clarity because although it may be true in general, in particular cases "the distinction among quasi-rents, Ricardian rents, and pure rents in practice is as controversial as competition policy itself" 182 and does not, in itself, resolve any of the trade-offs inherent in the intersection between IP law and antitrust. In sum, replacing the term monopoly with the term rent does not change the economic significance of IP rights and their ability to confer market power on their owners.

177. Dam, supra note 156, at 251.

178. See supra Part III.A.

179. Dam, supra note 156, at 251.

180. See id.

181. Id.

182. TREBILCOCK ET AL., supra note 153, at 55. 


\section{Perfect, Monopolistic, AND SChumpeterian COMPETITION}

The analysis in this part will consider another reason why markets in intellectual goods will often be dominated by few or even single sellers-much more often than the AGLIP acknowledge. It will consider three models of competition - perfect competition, monopolistic competition, and Schumpeterian competition - and explain why markets in intellectual goods often exhibit Schumpeterian competition.

\section{A. Perfect Competition vs. Monopolistic Competition}

Traditional antitrust analysis often begins by referring to the model of perfect competition. ${ }^{183}$ This model seldom applies to real-life situations, but it serves as a benchmark and as an ideal. Real markets will be measured by their departure from this perfect competition model; the closer they are to the model the more efficient they are considered. ${ }^{184}$

In practice, however, albeit not always consciously or explicitly, antitrust analysis often uses the model of monopolistic competition. ${ }^{185}$ This model depicts a market populated by relatively small firms selling differentiated products that consumers do not consider perfect substitutes, while entry and exit are unobstructed. Under conditions of monopolistic competition, each competitor faces a downward sloping demand curve and therefore sets its prices above marginal cost and earns supranormal returns - but only temporarily. If entry is free, the existence of supra-competitive profits will attract new entrants offering other differentiated products. Extra profits will be wiped out and price in equilibrium will equal the long run cost of production. ${ }^{186}$ That is, prices may be set above marginal cost, but only high enough to cover the total cost of production.

Indeed, in a sense, the concept of the relevant market reflects both the notion of perfect competition and the notion of monopolistic competition. Under perfect competition, there is only a single homogeneous product, and all competing sellers sell the same product. In this case, the product is the market. The antitrust relevant market, however, often includes not only the product in question and its perfect substitutes, but also other differentiated products that are often imperfect yet reasonable substitutes.

183. See, e.g., HovENKAMP, supra note $17, \S 1.1(\mathrm{a})$.

184. Id.

185. Id. $\S 1.5$ (arguing that the model of monopolistic competition has not had much explicit effect on antitrust policy, although judges must often consider how competition in the real world deviates from the model of perfect competition or monopolistic competition).

186. EdWARD Hastings CHAMBERlin, THE THEORY OF MONOPOlistic COMPETITION: A Re-ORIENTATION OF THE THEORY OF VALue 83-85 (8th ed. 1962). 
While the model of differentiated products and monopolistic competition may indeed describe many markets for intellectual goods, ${ }^{187}$ a few points are worth mentioning. One, under monopolistic competition there is always some degree of market power, in the sense of price above marginal cost. As a result, deadweight loss always exists because no matter how much entry occurs, the fact that the products are differentiated means that they are not perfect substitutes. ${ }^{188}$ Second, because the marginal cost of intellectual goods often approaches zero, we can expect that the distance of price from marginal cost will be greater compared to the case of goods with non-trivial marginal cost. ${ }^{189}$ Third, the model of monopolistic competition assumes free entry, ${ }^{190}$ and IP laws often interfere with free entry by preventing the entry of identical or almost identical goods, thereby requiring competitors to adopt a greater degree of differentiation. ${ }^{191}$

\section{B. Schumpeterian Competition}

What the concepts of perfect competition and monopolistic competition have in common is a focus on the products that compete against each other within a single time period. Even when the analysis takes a more dynamic approach, under the concept of potential competition for example, it looks at the firms that

187. See, e.g., Christopher S. Yoo, Copyright and Product Differentiation, 79 N.Y.U. L. REV. 212, 220 (2004) (arguing that this is the model that generally applies in the case of copyrighted works).

188. Id. at 249.

189. See supra Part III.B.1.

190. Yoo, supra note 187, at 236.

191. See supra Part III.B.2. It is true that patent law, by covering ideas, often requires greater differentiation than copyright law, which protects only expression and not the underlying ideas, thereby allowing freer entry by requiring smaller differentiation. Yet, even in the case of copyright, sellers cannot avoid liability by selling an identical or even substantially similar good under a different brand. This is a point that Christopher Yoo, among others, underestimates. Yoo argues that the idea-expression dichotomy satisfies the condition for free entry. Yoo, supra note 187, at 217-18. He notes that:

There are no barriers preventing another author from putting pen to paper and attempting to create a substitute for any written work. In other words, although copyright prohibits others from copying the specific words penned by J.K. Rowling without her permission, it does nothing to prevent any other person from writing stories about a school where children learn to perform magic. The inputs needed to create substitutes for more complex media are generally freely available.

Id. at 218 n.16. However, as opposed to sellers of ordinary goods, such as Coke and Pepsi, or sellers who offer competing brands of cottage cheese, all of which are substantially similar (if not almost-identical) and are differentiated primarily by their brand, nobody can copy the specific words penned by J.K. Rowling, not even with minor modification, and freely sell such rebranded copies under another title and author name. Copyright law, therefore, forces much greater differentiation than Yoo assumes. The case of works in the public domain demonstrates the difference. Many publishers publish differentiated versions of Shakespeare's works. The works themselves are identical, although the published texts may differ in format, the type of paper, additional commentary, or the goodwill associated with the publisher's brand, etc. Yet the choice with regard to the form and degree of differentiation is independent of the law. Such works, not works under copyright, are the equivalent to ordinary differentiated goods. 
could enter the market and supply the same or similar products within the geographic area following a price increase by the incumbent firm. ${ }^{192}$ Although the concept of potential competition uses two time periods, it still looks at the second period as a period in which multiple firms compete simultaneously, not sequentially, and prices are in equilibrium.

Yet the notion of innovation, which the grant of IP rights seeks to promote, reflects competition of a type to which neither the perfect nor the monopolistic models of competition seem applicable. In the context of innovation, the crucial issue is not which products compete with each other within a single time period, but rather how new products compete with each other over time. In this context, the focus is less on competing products sold simultaneously and the resulting equilibrium and more on a process in which new products displace old ones and which themselves will be later displaced by the next generation of products. In this "perennial gale of creative destruction,"193 as described and praised by Joseph Schumpeter, monopolies are common, but frequently swept aside by new ones. ${ }^{194}$ The competition that such monopolies face is not from a multitude of close substitutes but rather from

the new commodity, the new technology, the new source of supply, the new type of organization ... competition which commands a decisive cost or quality advantage and which strikes not at the margins of the profits and the outputs of the existing firms but at their foundations and their very lives. ${ }^{195}$

Schumpeter's description of the process of Creative Destruction was not limited to cases involving IP. In fact, his analysis barely mentioned IP. ${ }^{196} \mathrm{He}$ believed that this model generally described capitalist markets, that this process was "the essential fact about capitalism," and that the benefits from such system far outweighed the cost of any occasional monopolistic practice. ${ }^{197}$ Nevertheless, when Schumpeter spells out the benefits of this system, his language sounds familiar to an ear trained to the language of IP. He argues:

A system ... that at every given point of time fully utilizes its possibilities to the best advantage [a system that seeks to promote perfect competition] may yet in the long run be inferior to a system that does so at no given point of time, because the latter's failure to do so may be a condition for the level or speed of long-run performance. $^{198}$

192. HOVENKAMP, supra note $17, \S 13.4(\mathrm{a})$.

193. Joseph A. Schumpeter, Capitalism, Socialism \& Democracy 84 (3d ed. 1950).

194. Richard Schmalensee, Antitrust Issues in Schumpeterian Industries, AM. ECON. REV., May 2000, at 192, 192.

195. SCHUMPETER, supra note 193, at 84.

196. Mark Blaug, Why Did Schumpeter Neglect Intellectual Property Rights?, 2 REV. ECON. RES. COPYRIGHT ISS. 69, 70 (2005).

197. SCHUMPETER, supra note 193, at 83.

198. Id. 
The same arguments are made in favor of IP rights ${ }^{199}$ and the tradeoff implicit therein. $^{200}$

The resemblance between Schumpeter's description of the competitive process in capitalist economies and the logic of IP does not mean, however, that competition between copyrighted or even patented products will always be Schumpeterian. Because copyright law protects only expressions but not the underlying ideas, and because patents can often be narrow in scope or apply only to limited characteristics of otherwise competing products, no general conclusive argument can be made in this regard. Examples of monopolistic competition in many copyrighted and patented products are of course abundant. Nevertheless, in those cases where Schumpeterian elements characterize the competitive landscape, as can be expected in many cases involving IP rights, the concept of a defined market in which many producers compete against each other simultaneously, thus constraining any excess market power, will often chart an inadequate view of that landscape.

The AGLIP anti-presumption of market power clearly rests on a model of monopolistic competition, whereby "the intellectual property right confers the power to exclude with respect to the specific product, process, or work in question," but "there will often be sufficient actual or potential close substitutes for such product, process, or work to prevent the exercise of market power."201 This concept, however, is inapplicable to contexts that involve high degrees of innovation, whereby the novel product displaces the old precisely because it is superior. ${ }^{202}$ In such a case, the two cannot be seen as close substitutes in the sense of two products that hold their manufacturers to their costs. ${ }^{203}$ True, the existence of the new and superior product may discipline the price of the old and inferior,

199. The Schumpeterian model is mainly applicable to intellectual property rights such as patents and copyrights which are designed to stimulate innovation. Trademark law, for example, whose important function is to enable firms to name their products and create brands and differentiated products that consumers will be able to identify and distinguish between, see, e.g., LANDES \& POSNER, supra note 13, at 166-67, is highly correlated with the case of monopolistic competition. Generally, trademark law does not prohibit the introduction of similar or even identical products, only the introduction of products bearing similar or confusing names or identifying characteristics. See, e.g., Harold F. Ritchie, Inc. v. Chesebrough-Pond's, Inc., 281 F.2d 755, 760 (2d Cir. 1960).

200. Cf. F.M. Scherer \& DAVID Ross, Industrial Market Structure AND ECONOMic Performance 613 (3d ed. 1990) (The authors opened their discussion on patents and technological innovation with the following statement: "Making the best use of resources at any moment in time is important. But in the long run, it is dynamic performance that counts.").

201. AGLIP, supra note $6, \S 2.2$.

202. This is true not only of technical innovations but also of cultural products where "new releases" of books, films and music constantly enter the market and displace the older.

203. The phrase, "there will often be sufficient actual or potential close substitutes" could refer to the prospect of subsequent innovation. But the AGLIP do not say how long one should expect to wait for such a substitute, or whether "potential" means "products that are in development that we can actually see" vs. "products that will be developed tomorrow in response to today's high prices." 
but not vice versa, at least not to the same degree. ${ }^{204}$ In such circumstances, expecting that no (significant) market power will be exercised, as the AGLIP seem to assume, seems unrealistic. On the contrary, we can expect that firms who win the innovation race would be able to exercise market power. This is precisely what IP laws are designed to achieve given the risks of failure and the risks of appropriation by others. ${ }^{205}$ The AGLIP view that this may happen only in exceptional cases, and that when it does antitrust law can be applied just as it applies to any other form of property, can therefore be highly misleading, or at least uninformative, because in such cases the application of antitrust law will be the most contentious: highly sought by some plaintiffs observing high profits and strongly opposed by defendants seeking to preserve them. ${ }^{206}$

\section{Many Markets for Intellectual Goods are Schumpeterian}

Although IP rights, as such, may not create market power, market power protected by IP may be found in many industries for innovative and creative products as a result of some characteristic demand side economies of scale (such as direct and indirect network effects), supply-side economies of scale (such as large sunk costs or instant scalability), or a combination of both. These characteristics will be discussed below. ${ }^{207}$ Therefore, markets of intellectual goods will quite often be dominated by few or even single sellers, and competition will take the form of the Schumpeterian model: competition for the market rather than within it.

Demand-side economies of scale exist when a product becomes more valuable as more people consume it, at least until some level. ${ }^{208}$ Telephones, fax machines, and operating systems for personal computers are among the wellknown examples. ${ }^{209}$ When such demand-side economies of scale-also known as "network effects"- exist, one product or one technology tends to dominate the market and become the standard. ${ }^{210}$ At this point, the number of actual substitutes can be very low, even if there are plenty of equally functional alternatives that could function as substitutes in the absence of such effects. This phenomenon has been widely discussed and litigated in the case of the software industry, as well as in many electronic consumer goods, where issues of compatibility are important. ${ }^{211}$

204. See HovenKAMP, supra note 17, §3.3 (giving an example in which an inferior product should be excluded from the market in a monopolization claim against the seller of the superior, but included in the market in the case of a proposed merger between the two sellers).

205. See supra Part III.B.2.

206. Roberts \& Putnam, supra note 123, at 319.

207. For a discussion of the effect of sunk costs, see supra Part III.B.2.

208. See CARl SHAPiro \& HAL R. VARian, Information Rules: A StrategiC GUIDE TO THE NETWORK ECONOMY 179-80 (1999).

209. See, e.g., Ariel Katz, A Network Effects Perspective on Software Piracy, 55 U. TORONTO L.J. 155, 164-65 (2005).

210. Id.

211. See generally SHAPIRO \& VARIAN, supra note 208, at 173-225. Network effects played an important role in the Microsoft antitrust litigation. See United States v. Microsoft Corp., 253 F.3d 34, 49 (D.C. Cir. 2001); Schmalensee, supra note 194, at 194 95. 
To a lesser extent, similar effects appear in other intellectual goods as well. Indeed, Jorde and Teece make such an argument about innovative products generally. They attribute such effects to "cumulative learning.", "Once a technology is selected and used," they explain, "it is likely to generate further learning by userdeveloped enhancements, while the old technology will have no user interaction and thus will remain relatively stagnant. ${ }^{.13}$ The result is that consumers often tend to favor a single product at any given time, and other technologies, even those of similar intrinsic functionality, cease to be viewed as good substitutes. It does not mean that the market power of the successful technology is unchecked because higher profits will induce entry that might displace the current technology, but it means that until such entry occurs, an assumption that the exercise of market power is impossible is misleading.

Similar network effects exist in many cultural goods such as music, novels, and films, in which "winner-take-all" or "winner-take-most" situations frequently occur. ${ }^{214}$ Such effects exist because, while many of these products may have an intrinsic value regardless of the number of other people consuming them, it is often the case that the value of such goods increases with their consumption by other people because part of what consumers get from those goods is relevant social interactions. ${ }^{215}$ As Martin Kretschmer et al. note, "[w]e do not want to read books nobody else reads, we do not want to see movies nobody else sees. We want to discuss, rave, slaughter and define ourselves by the things we like.,216 Moreover, cultural goods' quality is often hard to discern before consumption and sometimes even after consumption. Therefore, consumers' choices will depend in part on what other people think and how many of them think so. ${ }^{217}$ As in the case of information technology, cultural goods may have direct network effects, whereby the value of the work increases with the number of other people consuming it because of the opportunities to interact and exchange views with other people (just as having the same software or hardware platform allows consumers to exchange files with each other). Cultural goods may also have indirect network effects, whereby the increased number of users induces the development of complementary products and services (e.g., compatible software and hardware, support services, and literature in the case of information technology; commentary, critique, parody, academic courses, fan clubs, in the case

212. Jorde \& Teece, supra note 119, at 582.

213. Id. Cumulative learning is just one aspect of positive externalities that characterize such markets. More generally, such externalities induce a positive feedback in which one technology attracts more complementary products and services than others.

214. See Guy Pessach, Copyright Law as a Silencing Restriction on Noninfringing Materials: Unveiling the Scope of Copyright's Diversity Externalities, 76 S. CAL. L. REV. 1067, 1084 (2003) ("[M]edia products consist of a cultural network effect. In many cases, the value of a media product for each individual is derived, at least partially, by its centrality and significance for other individuals.”). See generally ROBERT H. FRANK \& PHILIP J. COOK, THE WinNER-TAKE-All SOCIETY (1995).

215. Cass R. Sunstein \& Edna Ullmann-Margalit, Solidarity Goods, 9 J. PoL. PHIL. 129, 138 (2001).

216. Martin Kretschmer et al., Increasing Returns and Social Contagion in Cultural Industries, 10 BRIT. J. MGMT. 61, S63 (1999).

217. Id. 
of cultural products). Of course, many cultural networks are short-lived and narrow in $\operatorname{scope}^{218}$ (although some may be persistent and wide in scope; think of the cultural network of the Bible, for example), and unlike the case of many information technology markets where positive feedback may lead consumers to be locked-in, thereby increasing the market power of the sellers, cultural products have a much lower tendency toward lock-in. ${ }^{219}$ Nevertheless, the existence of such effects suggests that copyright, the domain of most cultural products, may be associated with more market power than usually assumed. ${ }^{220}$

On the supply side, "winner-take-all" (or most) outcomes are often accelerated by "instant scalability," which means that "a firm's output can be increased very rapidly without the usual additional costs associated with rapid increase in output. ${ }^{, 221}$ Economists Stan Liebowitz and Stephen Margolis have explained that instant scalability characterizes many industries "in which products consist principally of intellectual property."222 "In such industries, production of the good itself consists largely of reproduction of the tangible form of the intellectual property" ${ }^{223}$ and often this requires generic reproduction equipment rather than specialized fixed investments in new factories and new tools that are often large, product-specific, and irreversible. ${ }^{224}$ "In industries that are subject to instant scalability, winners can rapidly win big because they can rapidly scale up, and losers leave quickly because their investments in generic capacity are reversible." 225 Thus, one seller, whose product may be slightly better than another's, can rapidly satisfy the entire market. ${ }^{226}$

A similar observation on how supply-side economics can lead to situations of "winner-take-all" in many creative products was made by Sherwin Rosen in his study of the economics of superstars. ${ }^{227}$ Rosen noted that the technology of supply may be part of the explanation for the growing phenomenon of superstars, "wherein relatively small numbers of people earn enormous amounts

218. See Pessach, supra note 214, at 1085 (suggesting that, unlike pure economic network effects, cultural network effects are "more flexible and complicated," yet "less homogeneous and stable").

219. As Kretschmer et al., supra note 216, at S63, point out, "[s]eeing one movie does not prevent us from seeing another." See also Pessach, supra note 214, at 1085. Religion, at least in its monotheistic forms, of course, can be a counter example; monotheistic religions usually demand exclusivity from their worshipers.

220. See, e.g., Kitch, supra note 68, at 1730 (arguing that among IP rights, patents are "the strongest candidate for the monopoly case," whereas copyrights cover only forms of expressions but not the underlying ideas, and therefore confer less power on their owners).

221. Stan J. Liebowitz \& Stephen E. Margolis, Winners, Losers \& Microsoft: Competition AND Antitrust in High TeChNology 137 (1999).

222. Id. Software and any other content that can be digitized and easily reproduced are the obvious examples of this phenomenon.

223. Id.

224. Id.

225. Id

226. Id.

227. Sherwin Rosen, The Economics of Superstars, 71 AM. ECON. REV. 845, 846

(1981). 
of money and dominate the activities in which they engage." 228 According to Rosen, superstars will be found where the cost of reaching large audiences is low, often in cases of joint consumption, which "allows relatively few sellers to service the entire market. And fewer are needed to serve it the more capable they are." 229 Many cultural products exhibit this tendency because "the costs of production (writing, performing, etc.) do not rise in proportion to the size of a seller's market," and because the technology of supply allows the seller to deliver the service to many buyers simultaneously. ${ }^{230}$ Rosen noted that "[o]nce the author tells his tale to the publisher, it can be duplicated in writing as many times as desired. A performer appearing on television literally clones his performance to whomever happens to tune in." 231 Technical advancements, such as motion pictures, radio, television, phono-reproduction equipment, and communications have made it possible for sellers of cultural products to increase the scope of their audiences substantially. $^{232}$

The resulting picture of this analysis is that markets in intellectual goods will often be dominated by few or even single sellers - much more often than the AGLIP acknowledge. In such cases, competition will often take the form of competition for the market rather than within the market-competition of serial monopolies displacing each other. The danger of being eventually displaced by a new monopolist undoubtedly exerts a restraining effect on the behavior of the incumbent. This danger may restrain the incumbent monopolist's ability to raise prices, decrease output or lower the quality of service, knowing that each would create an opportunity for the next monopolist. It may dissuade the incumbent from resting on his laurels and encourage him to continue innovating. When all of this happens, antitrust should not be concerned. But at the same time, the incumbent may seek to delay his demise by resorting to anticompetitive acts, aimed at discouraging aspiring competitors. When this is the case, antitrust law may be justifiably concerned. ${ }^{233}$ Distinguishing between pro-competitive behavior and anticompetitive behavior (e.g., whether lowering the price in the face of rival entry is pro-competitive or anticompetitive) will not always be easy. Nor will it be clear whether antitrust intervention can be cost-efficient given the complexity of issues and the limitations of regulators and courts. ${ }^{234}$ In some cases, the market may be so small or transitory that the social cost of monopoly may not justify intervention. ${ }^{235}$ And of course, one should not neglect the benefit to society from the existence of the innovative product and ignore the danger that undisciplined imposition of antitrust laws on owners of successful intellectual goods might deprive IP laws of incentive function. ${ }^{236}$ But these are all considerations that should be made once we

228. Id. at 845 .

229. Id. at 847 .

230. Id.

231. Id. at 849 .

232. Id. at 856; see also LANDES \& POSNER, supra note 13, at 49-50.

233. See, e.g., Richard A. Posner, Antitrust in the New Economy, 68 AnTITRUST L.J. 925, 934-35 (2001).

234. Id. at 936-43.

235. Landes \& Posner, supra note 88, at 953; see also infra Part VIII.

236. Roberts \& Putnam, supra note 123, at 319. 
face a monopoly and have to determine the legality of its practices. The AGLIP suggest (or pretend) that more often than not we will not face them, whereas I suggest that on many occasions we will.

\section{Asking The Correct Questions}

Much of the confusion about the relationship between IP rights, market power, and the presumption of market power stems from the tendency to discuss this relationship, not in the context of specific antitrust problems, but rather in the abstract, as if markets and market power are things that have an actual presence in the world. But the term "market," when used in antitrust law and antitrust economics, does not have such actuality. Markets in antitrust are unlike markets in urban geography. St. Lawrence Market in Toronto, for example, is a real place, at the corner of Front Street East and Lower Jarvis Street. Any product sold there can be categorized as belonging to one or more antitrust markets. ${ }^{237}$ Markets in antitrust are only concepts used to answer specific questions, to decide whether an alleged practice is anticompetitive, ordinarily understood as being able to allow the party or parties in question to raise or maintain prices, reduce output, or perhaps cause other injuries that the law seeks to prevent. ${ }^{238}$ As Professor Salop explains: "Market definition and market power should be evaluated in the context of the alleged anticompetitive conduct and effect, not as a flawed [threshold] filter carried out in a vacuum divorced from these factors."239

Without a specific challenged conduct, a specific context, and an identified antitrust question that demands an answer, the market is an empty concept in antitrust analysis, and imprudent use of it may lead to certain traps. In response to this danger, antitrust wisely uses the term relevant market - seeking a definition of a market that is relevant for the understanding of the disputed restraint or conduct. ${ }^{240}$ This is also why a product could be defined as being part of different markets without any necessary inconsistency, depending on the underlying antitrust question. Consequently, because the whole purpose of the inquiry is to assess the effect of a specific restraint or conduct, the effect should be measured against some benchmark, and the proper benchmark is the price (or equivalent measurement) that would prevail in the absence of that restraint or conduct. $^{241}$

237. The market complex itself, owned by the City of Toronto, could be part of a relevant antitrust market; for example, the market for "commercial retail real estate in downtown Toronto."

238. See, e.g., infra Part VII.B (discussion about tying and consumer choice).

239. Steven C. Salop, The First Principles Approach to Antitrust, Kodak, and Antitrust at the Millennium, 68 AnTitrust L.J. 187, 191 (2000).

240. Jonathan B. Baker, Market Definition: An Analytical Overview, 74 ANTITRUST L.J. 129, 130 (2007) ("In antitrust analysis, a market is a collection of products and geographic locations, delineated as part of an inquiry aimed at making inferences about market power and anticompetitive effect. A market defined for this purpose is often termed a 'relevant market' or an 'antitrust market' in order to distinguish these markets from what business executives and consultants might define for other purposes." (citations omitted)).

241. Salop, supra note 239, at 196. 
In addition, much of the discussion about IP and market power reflects the notion that markets are either competitive or monopolistic; that firms either possess no market power because they face fierce competition or possess significant power because they are monopolies; and that monopoly is the antithesis of competition. ${ }^{242}$ The fact, however, is that unless the market is perfectly competitive (which is almost never the case) or unless we are dealing with a perfect monopolist who has control over the supply of all economic goods (which is never the case) both elements, competition and market power, always exist. ${ }^{243}$ At some point, every non-perfect monopolist faces a limit on his ability to further increase his prices, and at this point the monopolist may seem to behave like a firm in a competitive market in the sense that no further price increase can be profitably pursued. But identifying the market as competitive at this point may be misleading. This is essentially the "Cellophane Fallacy.",244

Therefore, the only questions that can be answered outside a context of a specific restraint or conduct, are whether a specific firm can or cannot set the price of its product above marginal cost, whether the firm covers its total costs or not, and similar questions. But generally these are uninteresting questions for antitrust. Of course, if the firm does set a price above marginal cost, then it could be said that it has market power, which could be substantial or not. But even if it is substantial, for antitrust law the possession of such power has never been unlawful, in fact, market power can be the outcome of the very competitive process which antitrust protects. The Supreme Court has expressly reaffirmed this point recently in Verizon Communications v. Law Offices of Curtis V. Trinko, where the Court stated:

The mere possession of monopoly power, and the concomitant charging of monopoly prices, is not only not unlawful; it is an important element of the free-market system. The opportunity to charge monopoly prices - at least for a short period-is what attracts "business acumen" in the first place; it induces risk taking that produces innovation and economic growth. To safeguard the incentive to innovate, the possession of monopoly power will not be found unlawful unless it is accompanied by an element of anticompetitive conduct. ${ }^{245}$

Thus, for any purpose other than analyzing a firm's ability to raise its own prices above marginal cost, the concept of market power is meaningless unless related to a specific challenged conduct. Therefore, the key issue is not attempting to differentiate the concept of market power in economics from the concept of market power in antitrust as some have suggested. ${ }^{246}$ Nor is the key issue merely a

242. CHAMBERLIN, supra note 186 , at 63

243. Id.

244. The Cellophane Fallacy will be discussed in Part V.A infra.

245. Verizon Commc'ns Inc. v. Law Offices of Curtis V. Trinko, LLP, 540 U.S. 398, 407 (2004).

246. See Klein \& Wiley, supra note 82, at 602 ("Antitrust market power as defined in case law thus is not an extreme form of economic market power, but is simply a different idea."); Lemley, supra note 80, at 996 n.26. Klein and Wiley argue that because markets are almost never perfectly competitive, "[i]t is only when a firm [has] a significant 
question of the degree of market power, whereby a small deviation from marginal cost is "not in an antitrust sense" but a significant one is. ${ }^{247}$ Instead, the concept of market power in antitrust can and should be understood as it is in economics: the ability of a firm to set its prices above marginal cost. Moreover, for most antitrust purposes, it is equally unnecessary to differentiate between "benign" market power (market power that yields only quasi-rents) and "malignant" market power (one that yields real rents, that is, in excess of what was required to call forth investment). The distinction is unnecessary because unlike some regulatory regimes that focus on the measurement of the regulated firm's degree of market power in order to set the "correct" price, the focal point of antitrust is (or at least should be) the change in market power. ${ }^{248}$ Antitrust looks at the effect of a specific restraint or conduct on the firm's (or the involved firms') ability to set their price higher or lower relative to a relevant benchmark, which should generally be the price (or other relevant variable) that would have existed but for the impugned conduct. For most antitrust questions, marginal cost is not such a benchmark. ${ }^{249} \mathrm{It}$ does not mean, however, that the distance of that benchmark from marginal cost may not be important. As we shall see below, for some antitrust questions it may be very important, but only after an anticompetitive effect resulting in an increase in market power has already been found.

impact on output and prices in ... [an] overall market," in contrast to impact on its own product's prices, that the firm can be said to have antitrust market power. Klein \& Wiley, supra note 82, at 631. The problem with this argument is that it uses the concept of the "market" as if it existed without connection to the alleged anticompetitive practice, whereas to define the market one needs to define the proper benchmark for the analysis. They argue that market power should be, and often is, measured against an appropriate benchmark that is not the firm's price-cost margin. $I d$. at 633 . While this is correct, it does not mean that market power in economics and market power in antitrust are different concepts. It only means that the market power will be measured against a benchmark that depends on the underlying antitrust problem.

247. Landes \& Posner, supra note 88, at 939.

248. See, e.g., R. Hewitt Pate, Assistant Attorney Gen., Competition and Intellectual Property in the U.S.: Licensing Freedom and the Limits of Antitrust, remarks before the 2005 Competition Workshop, Florence, Italy 8 (June 3, 2005), available at http://www.usdoj.gov/atr/public/speeches/209359.pdf. Pate stated:

Antitrust enforcers are not in the business of price control. We protect a competitive process, not a particular result, and particularly not a specific price. In fact, if a monopoly is lawfully obtained, whether derived from IP rights or otherwise, we do not even object to setting a monopoly price.

Id. There are exceptions though. As Hewitt points out, compulsory licensing of IP can be an effective remedy in some contexts. $I d$. at 10 . Because compulsory licensing requires that a tribunal or agency determine the fee payable to the IP owner (even if only as an ultimate arbiter), setting the fee involves this exercise in price control. In any event, compulsory licensing is rare, and because it is a remedy, it will only be applied if some other antitrust violation occurred. Setting high prices, in itself, would not trigger compulsory licensing.

249. I concede that this is an oversimplification. As a matter of antitrust doctrine, in some cases it is not the increase in market power, but the possession of it, which, combined with other acts, triggers liability. Courts have found several techniques to overcome the difficulty that this causes antitrust defendants. One of them is fudging the concept of market power. For a more detailed discussion, see infra Part VII.B. 
What follows is that identifying the exact conduct under scrutiny and determining how this conduct effects changes in the firm's market power constitutes the focus of the inquiry. Applying this to the question of the relationship between IP and market power requires identifying the conduct under investigation. If the question is how the existence of IP protection affects the firm's market power, then the challenged "conduct" is the grant of the IP right. The question here is how the grant of such a right affects the ability of the IP holder to set the prices for her goods above marginal cost. ${ }^{250}$ Obviously, we cannot provide an absolute answer to this question without empirically testing the effect in every individual case. There is always a possibility that the good would have no commercial value and its protection by an IP right would not change its price (zero). There is also the possibility that the existence of very close substitutes will force prices down to marginal cost. But as I have argued earlier, it is highly probable that this is not the general case, and that the existence of IP rights often allows their holders to set prices substantially above marginal cost, and that this may be particularly true in the litigated cases. When considering the effect of granting IP rights, it is therefore reasonable to presume, at least on grounds of probability, that market power is a likely effect.

\section{A. The Return of the Cellophane Fallacy}

The denial of the inherent connection between IP and market power results from failure to frame the correct question, and this failure may lead to what is often known in antitrust law as the "Cellophane Fallacy" or the "Cellophane Trap." The trap is the "[m]istaking [of] a firm's inability to exercise market power by raising price above the current price for an inability to have already exercised market power by raising price up to the current level, thereby mislabeling a completed anticompetitive act as a lack of market power." ${ }^{251}$ This trap has often awaited those who have dealt with the question of IP and market power and unfortunately many have been caught. Take the following excerpt from Professors Hovenkamp, Janis, and Lemley's treatise on IP and antitrust, whereby they explain why IP rights cannot generally bestow market power on their owners:

I might write an Italian cookbook that is protected by copyright. The copyright entails that no one else can copy my book or a significant portion of it. But notwithstanding the copyright, my book would enter a competitive field with hundreds of other Italian and perhaps more general cookbooks. My copyright confers substantial market

250. A legislative decision to grant IP rights and the effect on prices may be an important question of competition policy, though usually it is not a question of antitrust laws.

251. Salop, supra note 239, at 194. The trap originates from United States v. E.I. $d u$ Pont de Nemours \& Co., 351 U.S. 377 (1956). The case involved allegations of monopolization by Du Pont, who produced almost seventy-five percent of the cellophane sold in the U.S. and was engaged in a variety of practices that eliminated competition and enabled it to charge prices far above cost. Id. at 391-92. The Court focused on the inability to profitably increase the current price and concluded that the market definition was much broader so that Du Pont lacked any market power. Id. at 399-400. The Court's conclusions regarding lack of market power led it to forgo a detailed analysis of competitive effects. 
power only if my book is sufficiently desirable and sufficiently differentiated from the others that consumers are willing to pay a monopoly price for mine before substituting one of those. ${ }^{252}$

The excerpt defines a relevant market ("field") for Italian cookbooks or even the broader market for cookbooks, which in either case are assumed competitive, implying that no market power can be exercised in the form of monopoly price above this competitive level. Accordingly, any attempt by the authors or publishers to raise the price of their own Italian cookbook will cause consumers to purchase other cookbooks and render such a price increase unprofitable. This might be true, but it is an answer to the wrong question.

Rather, the appropriate question for addressing the relationship between copyright and market power is: what would have happened to price without copyright protection? Presumably, other things being equal, without copyright protection the price of the Italian cookbook, as well as of other books, would fall toward marginal cost. Instead, the excerpt implicitly asks whether the copyright holder is capable of profitably raising the price of the book above its current level. Presumably the answer is no, but this answer tells us very little about the existing market power. It only demonstrates that the exercise of market power, whatever its degree, is limited. But recall that the fact that market power is limited is entirely consistent with monopoly pricing. The monopolist will always try to raise its price up to the level where further increases will be unprofitable.

This does not imply that the ability to further raise the current price is irrelevant for antitrust analysis. On the contrary, often this is the question. But it is a different question. For example, if the inquiry is into the possible anticompetitive effects of a proposed merger between the publisher of "The Italian Cookbook" and the publisher of the "The Complete Guide to Italian Cooking," a finding that no further price increase is possible is extremely relevant. This finding means that the merger is unlikely to be anticompetitive. ${ }^{253}$ But that question, of course, is entirely different from the question of the relationships between copyright and market power. Now the question focuses on the effect of the merger on the parties' pricing abilities, and the benchmark for the analysis is the pre-merger price. The fact that the publishers have already had the ability to set their prices above marginal cost by virtue of their copyrights, even substantially, is irrelevant, at least at this stage of the investigation. But the finding that no further price increase is possible should not be mistaken as an inability to raise the price up to the current level; this is the Cellophane Fallacy. A conclusion that copyright confers no market power on the publishers of the Italian cookbooks is possible only if it has been established that competition forces their prices down to the marginal cost of printing and distribution. This, presumably, is not the case.

\section{B. When Is Existing Market Power Relevant?}

The preceding paragraphs showed that generally firms' existing market power is irrelevant for antitrust analysis, where the focus is on changes in market

252. HOVENKAMP ET AL., supra note $66, \S 4.2(\mathrm{a})$.

253. Such a merger can be pro-competitive if, as a result of the merger, the parties will be able to save some production costs and lower their price. 
power. However, there are times when firms' existing market power is indeed relevant for antitrust analysis. For example, if the challenged conduct is a proposed merger between the cookbook publishers, or an agreement under which one publisher distributes the book of the other, and the investigation reveals that a postmerger or post-agreement price increase is possible, then the fact that both publishers have already set their prices substantially above marginal cost by virtue of their IP rights can and should be relevant in assessing the overall impact of the merger. ${ }^{254}$

Ideally, setting asides problems of measurement, we would like to measure the potential efficiency gains from the merger (e.g., reducing overhead costs of publishing) against the potential welfare loss from the price increase. If we want to measure this balance correctly, knowing how far above marginal cost the pre-merger price is becomes crucial because the last increment of monopoly pricing produces larger amounts of deadweight loss. ${ }^{255}$ But note that we have now asked a different question. Now the question is no longer whether price increases as a result of the merger. The question has become, assuming that such price increase is likely, how the merger affects total surplus in the market; that is, the net effect of the efficiency gains and deadweight loss. At this stage of the analysis, the question of whether the seller had already exercised market power can be crucial. The higher the market power already exercised, the bigger the deadweight loss resulting from any further price increase, and therefore, the greater the efficiency gains required to offset that loss under a standard of total surplus. ${ }^{256}$ Consider the following examples, based on ones given by Professors Mathewson and Winter in a slightly different context. ${ }^{257}$

254. See Frank Mathewson \& Ralph Winter, The Analysis of Efficiencies in Superior Propane: Correct Criterion Incorrectly Applied, 20 CAN. COMPETITION REC. 88, 92-93 (2000) (criticizing the decision of the Canadian Competition Tribunal in Comm'r of Competition v. Superior Propane, Inc., [2000] Comp. Trib. 15, whereby the Tribunal approved a merger that was predicted to cause an average price increase of nine percent, on the basis that the predicted efficiencies that the merger would create outweighed the loss from the price increase, while failing to consider that because the parties to the merger were already exercising market power by charging a price that was fifty percent above marginal cost, the actual deadweight loss was 8.5 times higher).

255. Ayres \& Klemperer, supra note 103, at 987 (arguing that uncertainty and delay in patent litigation is beneficial because it restrains the patentee's monopoly power at the margin where additional power creates significant deadweight loss with relatively small additional profit for the patentee, thus having insignificant effect on the incentive to innovate); see also Mathewson \& Winter, supra note 254, at 92-93; Salop, supra note 239, at 195 n.20 (citing Raymond Jackson, The Consideration of Economics in Merger Cases, 43 U. CHI. J. Bus. 439 (1970)).

256. Mathewson \& Winter, supra note 254, at 92-93. I set aside the debate on the so called "Efficiency Defense" in mergers, the question of whether and when expected efficiency gains could justify a merger that leads to an increase in price, and whether "total surplus" is the correct standard. For the purpose of this example, I assume that such defense exists and that the standard for its application is "total surplus." For a general discussion of the issue in U.S. antitrust law, see HOVENKAMP, supra note 17, § 12.2.

257. Mathewson \& Winter, supra note 254, at 92. 
Example 1: Let us examine the hypothetical proposed merger between the book publishers discussed above. Assume that prior to the merger there are 100 consumers and each purchases one (generic) book on Italian cooking. The market is highly competitive so that the initial price equals marginal cost of $\$ 10,{ }^{258}$ but as a result of the merger the price increases by $10 \%$ to $\$ 11$. Because the price has increased, those consumers whose willingness to pay was between $\$ 10$ and $\$ 11$ exit the market. Assume that there are 10 of them. The loss in surplus associated with each of them is the difference between each consumer's willingness to pay and marginal cost, which is on average $\$ 0.5$ for each consumer, and the total loss is $\$ 5(10 \times 0.5)$.

Example 2: Now consider a slightly different scenario. Marginal cost is still $\$ 10$; however the pre-merger price is $\$ 100$ per copy-a ratio not uncommon for intellectual goods, as has been shown earlier. ${ }^{259}$ The percentage price increase as a result of the merger is still $10 \%$, and as before there are initially 100 consumers and 10 of them, who are not willing to pay $\$ 110$ are discouraged from buying. Now again the loss in total surplus associated with each of them is the difference between each consumer's willingness to pay and marginal cost, which is on average $\$ 95$ for each consumer, and a total of $\$ 950$ (10 X 95). This is quite a large number and the difference between the magnitudes of the losses is remarkable. The difference exists because in the first case those consumers who were discouraged by the price increase were those who value such books only slightly above cost, whereas in the second those who were discouraged by the price increase were consumers who value the books highly. ${ }^{260}$

In a world of full and free information, the decision whether to approve or condemn the merger would be easy. The merger should be endorsed so long as the efficiency gains outweigh the deadweight loss caused by the price increase, but condemned if the loss outweighed the gains ${ }^{261}$ Regrettably, we do not live in such a world. It is not uncommon that we will not have sufficient and reliable information about the costs and have even less so about the expected efficiency gains.

This is when presumptions may be useful for making decisions with greater probability of resembling a world of full and free information. If we follow the AGLIP, we assume that we are in Example 1 and that pre-merger the publishers could not exercise market power. ${ }^{262}$ In this case, given the uncertainty about the expected efficiency gains, the cost of error in endorsing the merger is $\$ 5$ at the maximum (i.e., when there is $10 \%$ increase in price and no efficiency gains).

258. I assume here that the pre-merger price equals marginal cost for the purpose of simplifying the example. Because the books are likely to be at least slightly differentiated, some market power may be exercised even prior to the merger. In this case, the deadweight loss that is created by the merger is greater. This does not affect the point of these examples, which is that the larger the distance of the pre-merger price from marginal cost, the greater the deadweight loss created by the merger.

259. See supra Part III.B.1.

260. Mathewson \& Winter, supra note 254, at 92.

261. See, e.g., 4A Phillip E. AreEdA ET AL., ANTITrust LaW 970 (2000).

262. Recall that under the AGLIP, there is no presumption that IP rights create market power in the antitrust context. AGLIP, supra note $6, \S 2.0(\mathrm{~b})$. 
Given this very low cost of error, we should endorse the merger even if the evidence supporting the efficiencies is very weak. In contrast, if we can infer from the existence of IP rights that the pre-merger price has already been set substantially above marginal cost — not an unreasonable proposition as we have seen - then it is more likely that we are in Example 2. The cost of error in this case is substantial $-\$ 950$ - and given the uncertainty about the magnitude of the expected efficiency gains, we should endorse the merger only if there is strong evidence that such gains are substantial.

This analysis is not exclusive to merger cases, but is applicable to many other antitrust inquiries, such as vertical restraints. ${ }^{263} \mathrm{~A}$ vertical restraint imposed by an IP owner that does not increase prices should be legal, regardless of the IP holder's existing market power. But if the restraint is likely to raise prices to some extent, then the fact that the IP owner has already had the ability to exercise market power affects the overall impact of the practice. The higher the degree of market power already exercised, the higher the deadweight loss caused by a further increase in prices, and the larger the efficiency gains required to outweigh this cost. It could be argued that in the case of IP there are additional offsetting benefits, in the form of incentive to innovate, which should justify different, more lenient antitrust standards to evaluate IP-related conduct. Whether the law should adopt a different standard for IP-related cases is beyond the scope of this Article. The point here is that such an approach would be in contrast to the AGLIP, which maintain that the same antitrust principles should apply to IP-related conduct. ${ }^{264}$

I have shown that the prices of many intellectual goods can be expected to be set substantially above marginal cost. Whether this fact justifies a legal presumption that they do is a different question discussed below. What is already clear is that the merit of the presumption cannot be divorced from the underlying antitrust question. However, before pursuing this question, it is useful to better understand what legal presumptions are and the reasons for their adoption.

\section{Presumptions-A Short Primer}

So far I have shown that IP rights and market power are inherently connected and slightly touched upon the role that presumptions play. But in order to evaluate the merit of having a legal presumption that IP rights confer market power as a matter of policy, it is useful to first explore what legal presumptions are and why they exist.

A legal presumption is "a rule providing that proof of a designated fact has a predetermined effect in establishing the existence of another fact." ${ }^{265}$ It is "a process or a legal consequence whereby we infer the existence of a presumed fact

263. Black's Law Dictionary defines vertical restraint as "[a] restraint of trade imposed by agreement between firms at different levels of distribution (as between manufacturer and retailer)." BLACK's LAW DictiONARY 1340 (8th ed. 2004). For an example of vertical restraint, see infra Part VIII.

264. Id. $\S 2.2$.

265. Roger C. Park et al., Evidence Law: A Student's Guide to the Law of EVIDENCE AS APPLIED to AMERICAN TRIALs 102 (1998). 
when certain other basic facts have been established by evidence."266 Some presumptions are "conclusive" or "irrebuttable," meaning that a proof of the basic fact mandates a conclusion of another fact, despite evidence to the contrary. In such cases, evidence to the contrary is irrelevant and will therefore not be admissible. ${ }^{267}$ At the other end of the spectrum lies the concept of "permissive inference," a factual conclusion that the factfinder may, on the basis of simple everyday logic, draw from another fact or group of facts, but is not required to. ${ }^{268}$ In between are "rebuttable" presumptions, which can be either of two types, depending on the effect of the production of rebutting evidence. One type is the Thayer-Wigmore or the "bursting bubble" theory of presumptions. Under this theory, the effect of a presumption disappears with the production of evidence challenging the presumed fact. ${ }^{269}$ In contrast, the Morgan-McCormick theory of presumptions asserts that once a presumption is raised by proof of the basic facts, the burden of persuasion as to the existence of the presumed fact shifts to the other party; that is, the presumed fact is deemed to exist unless the other party persuades the factfinder that it is more likely than not that the presumed fact is not true. ${ }^{270}$

Presumptions exist for a variety of reasons. The most frequently articulated reason is probability - when judges believe that the proof of one fact renders the existence of another so probable that it is sensible and timesaving to assume the truth of the presumed fact, at least until the fact is disproved by the adversary. ${ }^{271}$ Some presumptions are created in order to "correct an imbalance resulting from one party's superior access to the proof." 272 This consideration is often seen as a matter of fairness. ${ }^{273}$ However, it could be equally framed in terms of efficiency: if one party has better access to the proof, having a presumption in favor of her opponent improves the judicial process by creating an incentive to produce the evidence by the party who can obtain it at lower cost. This may reduce both the cost of an erroneous decision and the system's administrative cost. ${ }^{274}$ Some presumptions are adopted to avoid an impasse and reach some result, even an arbitrary one, when there is no factual basis upon which to decide. The creation of many other presumptions reflects some underlying social or economic policy and is closely tied to the pertinent substantive law. ${ }^{275}$ Such presumptions are created "to encourage or discourage certain 'primary' (non-litigation) behavior, or

\footnotetext{
266. Ronald J. Delisle, Evidence: Principles And Problems 183 (5th ed. 1999).

267. PARK ET AL., supra note 265, at 105.

268. Id.

269. Id. at 109.

270. Id. at $111-13$.

271. 2 Charles T. MCCORMick, McCormick ON Evidence 500-01 (6th ed. 2006); PARK ET AL., supra note 265, at 104.

272. 2 MCCORMICK, supra note 271 , at 500 (giving as example the rule that as between connecting carriers, the damage occurred on the line of the last carrier, if the shipper proves that he delivered the goods to the first carrier in good condition and received them from the last in bad condition).

273. Id.

274. On the economics of legal procedures, see generally RICHARD A. POSNER, ECONOMIC ANALYSIS OF LAW 599-600 (5th ed. 1998).

275. 2 MCCORMICK, supra note 271, at 501.
} 
to effectuate a goal of the law." ${ }^{276}$ Individual presumptions often exist for a combination of these reasons, not only one. ${ }^{277}$

My analysis so far has focused on the issue of probability. I have shown that it is highly probable that in many instances IP rights confer upon their owners the power to set prices for their intellectual goods substantially above marginal cost and that this is even more likely in situations that are litigated. While this may justify a presumption of market power based on probabilities, it does not resolve the issue of whether, as a matter of policy, such a presumption should exist. As noted earlier, one difficulty is that a presumption makes it easier for plaintiffs to sue, thereby increasing the number of defendants and reducing the average amount of market power held by them, and thus changing the probabilities on which the very presumption is based. ${ }^{278}$

Moreover, mere probabilities will not resolve the debate on the merit of a presumption of market power even if market power in IP litigation were much more or much less frequent than I expect. By definition, every presumption may require a factfinder to reach a factual conclusion (sometimes mandating a certain legal conclusion) that does not reflect reality, or may even contradict it, if the presumption is not rebutted. ${ }^{279}$ This is especially so if a presumption is created to further a certain social or economic goal. Such policy goals can justify the existence of a presumption despite the fact that it will not reflect reality in a large number of cases or reject a presumption even though it will be empirically correct. $^{280}$ For example, per se rules in antitrust law create a presumption, often

276. PARK ET AL., supra note 265, at 103-04 (providing as an example the presumption of the death of a person not heard from for a specific period of years, which serves the goal of settling issues of title and estates).

277. 2 MCCORMICK, supra note 271, at 501.

278. See supra Part III.C.

279. PARK ET AL., supra note 265, at 103.

280. Take for example the presumption that the child born to a woman during the time when she was married is the child of the husband. Apparently, this presumption is based on probability. It reflects a common reality that children are ordinarily the genetic product of the husband and wife who raised them, but it also reflects procedural efficiency because it would have been difficult to know even if they were not. See, e.g., Elizabeth Bartholet, Guiding Principles for Picking Parents, 27 HARV. Women's L.J. 323, 324 (2004). Although controversial, the presumption continues to stand despite the fact that DNA tests can provide a clear answer as to who the biological father is, and despite the fact that recent studies show that surprisingly high percentages of children born in the context of marriage or marriage-like relationships are not genetically related to their mothers' partners. These developments undermine both the procedural efficiency and the probability rationales for the presumption. See id. The presumption is upheld because it serves important policy goals: one, avoid the social stigma and some legal consequences of being born out of wedlock, see 2 MCCORMICK, supra note 271, at 505-06, and another, more modern consideration is that the presumption promotes the interests of children who need permanent nurturing parents, see Bartholet, supra, at 338.

An opposite example is the presumption of innocence in criminal law, requiring the prosecution to prove the case against a suspect beyond a reasonable doubt. This presumption exists despite the fact that most suspects are usually ultimately convicted. See, e.g., J. Mark Ramseyer \& Eric B. Rasmusen, Why is the Japanese Conviction Rate So High?, 30 J. LEGAL STUD. 53, 55 (2001) (conviction rates in the U.S. in 1995 were over 
conclusive, "that certain agreements or practices are so 'plainly anticompetitive,' and so often 'lack ... any redeeming virtue,' that they are conclusively presumed illegal without further examination under the rule of reason generally applied in Sherman Act cases." ${ }^{281}$ Such rules are adopted despite the fact that some agreements and practices, which fall into one of the categories to which per se rules apply, could in fact be pro-competitive. However, it is assumed that the cost of acquiring relevant information in order to reach the right decision with regard to each and every one of them exceeds the marginal benefit from having a more accurate decision. ${ }^{282}$ It is therefore assumed that, as a matter of policy, it is better to err on the side of condemning some pro-competitive agreements rather than allowing some anticompetitive ones.

Some policy considerations could theoretically support the creation of a presumption of market power despite the fact that in many cases IP rights confer a very small amount of market power or none at all. Other considerations could similarly support not adopting such a presumption even if the number of IP holders that do have market power overwhelmingly exceeds the number of those who do not. The answer largely depends on one's assumptions about the relative importance of the various considerations, as well as on one's beliefs about what the consequences of adopting one rule over the other are. For instance, a presumption may be supported because: (1) it is easier for an IP holder to prove that she does not have market power because she has better access to the relevant information; (2) the social cost of anticompetitively exercising market power is deemed significant; and (3) the social cost of erroneously restraining some practices when no market power exists is deemed relatively small. In contrast, a presumption of market power may be disfavored because: (1) by helping plaintiffs it may lead to the erroneous condemnation of too many benign practices; or (2) it will inflate the number of antitrust claims against IP holders, whether justified or not; and (3) such developments would negatively affect the incentives to innovate and would consequently lead to a reduction in consumer welfare. Consequently, no one-size-fits-all evaluation of these often conflicting considerations, applicable to all antitrust inquiries, exists. In order to evaluate the merit of a presumption of market power, we must first understand and define the specific issue that needs to be resolved and, if this is an antitrust issue, what the challenged practice is, along with its alleged anticompetitive results. We must also examine the legal consequences of a factual finding that the defendant has market power. Only then, in conjunction with the underlying substantive laws and surrounding procedural rules, can we assess the potential benefits and costs of having or rejecting a

eighty-three percent and over eighty-seven percent in federal and state criminal courts, respectively, and over ninety-nine percent in Japan). In theory, probability and procedural efficiency could support a presumption of guilt whenever a suspect has been properly indicted, say, after an impartial investigation had been carried out by police (recall that law generally presumes that the official actions by public officers were regularly and legally performed). Nevertheless, the law rejects such a presumption of guilt on policy grounds, taking the view that the cost of a false conviction outweighs the cost of false acquittals. See, e.g., In re Winship, 397 U.S. 358, 363-64 (1970).

281. Broad. Music, Inc. v. Columbia Broad. Sys., Inc., 441 U.S. 1, 8 (1979) (citations omitted).

282. See, e.g., HovenKAMP, supra note $17, \S 5.6(\mathrm{~b})$. 
presumption of market power. Of course, these analyses may diverge across various antitrust contexts. In addition, because the existence of a presumption of market power influences the empirical basis for its correctness, a pendulum movement in courts' willingness to infer market power from the existence of IP rights can be expected and may be justified. In sum, without accounting for all of those considerations, any discussion of the presumption or the lack thereof is futile. The Supreme Court's observation that IP rights do not necessarily confer market power ${ }^{283}$ is just one relevant factor; it certainly does not end the inquiry.

I next turn to evaluating the merit of having a presumption of market power in three different antitrust contexts: merger cases, tying cases, and cases involving attempts to enforce invalid IP rights. I show that depending on the context and the relevant antitrust questions, the substantive theories of liability and the relevant procedural and evidentiary rules, a presumption of market power can be a beneficial instrument in some contexts, while irrelevant or harmful in others.

\section{Can a Presumption of Market Power Make Sense?}

\section{A. Merger Cases}

Consider the hypothetical merger discussed earlier in Part V.B, and further assume that the merger is reviewed under a standard of total surplus, meaning that efficiencies created by the merger are weighed against any price increase resulting from it. The merger is allowed if the efficiency gains are greater than the deadweight loss caused by the increase in price. Assume that the merger is likely to have mixed effects, in that there will be some possible price increase and a resulting additional deadweight loss, as well as some efficiencies, but that the certainty and magnitude of each effect are not exactly known. Can a presumption of market power assist in reaching the result that most likely would increase total surplus under these conditions of uncertainty?

Recall that the same increase in post-merger market power creates greater deadweight losses if the merging firms have pre-merger market power (as in Example 2) and smaller losses if there is no pre-merger market power (as in Example 1), ${ }^{284}$ and that a presumption of market power would require the demonstration of greater efficiencies in order for the merger to pass the test of legality. Recall also that, as a matter of probability, commercially valuable IP rights often confer market power, so that if the merger is going to increase prices, the situation described in Example 2 is more likely than that of Example 1. ${ }^{285}$ This may be a consideration in favor of a presumption of market power, yet definitely not a determinative one. Considering the additional rules applicable to this case would be helpful.

283. Ill. Tool Works Inc. v. Indep. Ink, Inc. (ITW), 547 U.S. 28, 45 (2006).

284. See supra Part V.B. In Example 1, a ten-percent increase in post-merger market power created $\$ 5$ of deadweight loss (when price went up from marginal cost of $\$ 10$ to $\$ 11$ ), and in Example 2, the same ten percent increase in post-merger price created $\$ 950$ of deadweight loss (when price went up from $\$ 100$ to $\$ 110$ ).

285. See supra Part V.B. 
Unlike per se rules against price-fixing, which create a conclusive presumption of harm to competition, the burden of persuasion in merger cases rests on the challenging party. ${ }^{286}$ This reflects the perception that most mergers are unlikely to harm competition and in fact may increase efficiency. ${ }^{287} \mathrm{In}$ a sense, the rules applicable to mergers contain a presumption that mergers are procompetitive, although they require the merging firms to demonstrate efficiencies if the challenging party produces evidence showing that the merger will likely increase market power. ${ }^{288}$ Yet, the ultimate burden with regard to the overall anticompetitive impact remains with the challenging party.

Recall, however, that the cost of error in approving a merger when premerger market power exists is high when the efficiencies are small. I assume that much of the relevant information necessary for such an analysis is more readily available to the merging firms than to the challenger. The problem, however, is that given the current burdens of proof, the merging firms do not have good incentive to provide the information unless the challenging party has been successful in demonstrating significant anticompetitive effect, a task that may not be easy. Therefore, a presumption of market power encourages the merging firms to provide meaningful information regarding the expected efficiencies and thus improves the quantity and quality of information before the court, and increases the expected quality of the court's decision.

But a downside also lurks. A presumption makes it easier to challenge such mergers and may raise a concern about strategic challenges of efficient mergers by less efficient competitors. Such competitors might attempt to block a merger precisely because it is efficient and makes their lives as competitors more difficult rather than because it is anticompetitive. ${ }^{289}$ How serious this concern is and whether it suffices to reject the presumption depends on other rules pertaining to the litigation of merger cases, such as the rules determining who may challenge the merger, on what grounds they may challenge it, and what remedies are available to them. For example, the availability of the treble-damages remedy increases the incentive to challenge mergers. On the other hand, since American courts adopted the doctrine of "antitrust injury," which imposed stricter standing requirements and narrowed the scope of actionable harms, who may challenge and on what grounds have been constricted. ${ }^{290}$ The concern about strategic challenges of efficient mergers would be even smaller in a jurisdiction such as Canada, where only the Competition Bureau, not private parties, may challenge mergers. ${ }^{291}$

286. AREEDA ET AL., supra note 261, at $9976 \mathrm{~d}$.

287. See, e.g., HovenKAMP, supra note $17, \S 12.1$.

288. See AREEDA ET AL., supra note 261, at $9976 \mathrm{~d}$.

289. HOVENKAMP, supra note 17, at 497.

290. The doctrine of antitrust injury adopted by the United States Supreme Court in Brunswick Corp. v. Pueblo Bowl-O-Mat, Inc., 429 U.S. 477 (1977), and later refined in Cargill, Inc. v. Monfort of Colo., Inc., 479 U.S. 104 (1986), requires that the private plaintiff show that her injury is "of the type the antitrust laws were intended to prevent[,] . . flows from that which makes the defendant's acts unlawful," and reflects "the anticompetitive effect ... of the violation." Brunswick, 429 U.S. at 489.

291. See TREBILCOCK ET AL., supra note 153, at 196-97. 
My intention is not to solve the question about the desirability of a presumption of market power in merger cases, only to demonstrate that under different conditions a presumption may make more or less sense. Note, however, that even if adopted, the presumption is not that mergers between holders of IP rights are presumptively anticompetitive. It is only a rebuttable presumption that holders of IP rights possess a non-trivial amount of pre-merger market power, which, under my proposed framework, becomes relevant only after an anticompetitive effect of the merger has been demonstrated. It does not change the general presumption in favor of mergers and does not discharge the challenger from its burden to demonstrate an anticompetitive effect.

\section{B. Tying Cases}

I will now evaluate the merit of the presumption of market power in cases involving allegedly unlawful tying arrangements and show how the merit of the presumption changes according to different theories of liability and relevant procedural and evidentiary rules. Tying cases, in which sale of one product or service is conditioned on the buyer taking another product or service, are the ones in which the presumption of market power has been applied most frequently. ${ }^{292}$ Recently decided, ITW ${ }^{293}$ is a textbook example of such cases, so a brief description of the case will be useful.

Trident, a wholly-owned subsidiary of Illinois Tool Works, manufactures printheads and holds patents over its printhead and ink-container technologies. ${ }^{294}$ Printer manufacturers ("OEMs") use Trident's printheads in the printers they manufacture, which end users then use for placing barcodes on cartons. ${ }^{295}$ Trident also manufactures unpatented ink for use with its printhead technology and its agreements with OEMs require them to purchase ink exclusively from Trident. ${ }^{296}$ The agreements also require that neither the OEMs nor their customers refill the patented ink containers with any other manufacturer's ink. ${ }^{297}$

Independent Ink developed an ink with the same chemical composition as the one sold by Trident. ${ }^{298}$ It sued Trident and Illinois Tool Works alleging, inter alia, an illegal tying arrangement in violation of section 1 of the Sherman Act. ${ }^{299}$ The district court dismissed the case on summary judgment, but on appeal the Federal Circuit reversed. The Federal Circuit classified Trident's license agreement as an "explicit tying agreement conditioning the sale of a patented product (the printhead) . . . on the sale of an unpatented one (the ink). ${ }^{, 300}$ The Federal Circuit then found that because the Supreme Court had clearly established a presumption of market power in patent and copyright tying cases, no proof of

292. See HovenKAMP ET AL., supra note 66, § 4.2(e)(5).

293. Ill. Tool Works Inc. v. Indep. Ink, Inc. (ITW), 547 U.S. 28 (2006).

294. Id. at 31.

295. Id. at 32.

296. Id. at $31-32$.

297. Id.

298. Id. at 32 .

299. Id.

300. Indep. Ink, Inc. v. Ill. Tool Works, Inc., 396 F.3d 1342, 1345 (Fed. Cir. 2005), vacated, 547 U.S. at 46. 
market power by Independent was required. ${ }^{301}$ The Federal Circuit added, however, that the presumption is rebuttable. Therefore, "[o]nce the plaintiff establishes a patent tying agreement, it is the defendant's burden to rebut the presumption of market power and consequent illegality that arises from patent tying," and "[t]he presumption can only be rebutted by expert testimony or other credible economic evidence of the cross-elasticity of demand, the area of effective competition, or other evidence of lack of market power., ${ }^{302}$

The question before the Supreme Court was:

[w] hether, in an action under Section 1 of the Sherman Act . . . alleging that the defendant engaged in unlawful tying by conditioning a patent license on the licensee's purchase of a nonpatented good, the plaintiff must prove as part of its affirmative case that the defendant possessed market power in the relevant market for the tying product, or market power instead is presumed based solely on the existence of the patent on the tying product. ${ }^{303}$

Informed by and consistent with the "virtual consensus," the Court held that because "a patent does not necessarily confer market power upon the patentee ..., in all cases involving a tying arrangement, the plaintiff must prove that the defendant has market power in the tying product." ${ }^{304}$ The Court also declined the invitation to endorse a rebuttable presumption, again referencing the academic commentary's view that many tying arrangements "are fully consistent with a free, competitive market." ${ }^{305}$

The Court's explicit rejection of the presumption relies on the empirical argument that a patent does not necessarily confer market power. But as we have seen earlier, the empirical question of whether IP rights confer market power is only one parameter that needs to be considered. Equally important are considerations about the effectiveness of the judicial process, what policies or results a presumption may enhance or discourage, and how the presumption interacts with the underlying substantive theories of liability and the relevant procedural and evidentiary rules that apply to such cases. Considering those factors, it will become apparent that the presumption of market power in tying cases has indeed been problematic — even harmful—but not because it lacks empirical foundations. It has been problematic because it aggravated an alreadyexisting, flawed substantive theory of illegality about tying.

\section{Why Was the Presumption Harmful?}

Until its recent repeal, the presumption of market power in tying cases was harmful because it was a procedural rule that helped plaintiffs establish liability on the basis of a flawed theory of harm. Despite some ambiguity about the contents of the tests for illegality, under U.S. antitrust law tying arrangements are

\footnotetext{
301. Id. at 1352 .

302. Id.

303. Brief for the Petitioners at i, ITW, 547 U.S. 28 (No. 04-1329), 2005 WL

304. ITW, 547 U.S. at $45-46$.

305. Id. at 45 .
}

1864122. 
per se illegal (that is, without a requirement that the plaintiff proves harm to competition) when certain conditions are met. ${ }^{306}$ The conditions for illegality are usually met by a showing that there are separate tying and tied products and that the defendant possesses sufficient market power. ${ }^{307}$ It should be noted, though, that the per se rule for tying is not entirely per se (as is the rule against naked pricefixing $)^{308}$ because proof of market power is required, and in some cases the seller may avoid liability by showing an efficiency-based justification for the tie. ${ }^{309}$ But in any event, the defendant's possession of sufficient market power constitutes a requirement for finding an illegal tie, and until ITW the Supreme Court had held that " $\mathrm{t}]$ he requisite economic power [necessary for a finding of an antitrust violation] is presumed when the tying product is patented or copyrighted.,

The per se treatment of tying arrangements has been severely criticized as irrational. First, because it has been based on misguided assumptions that tying is generally used to leverage one's monopoly in one market into another or otherwise have an anticompetitive effect, and second because courts developed it without much regard to the various possible economic functions of tying arrangements and often by ignoring that tying may in fact be pro-competitive. ${ }^{311}$

Because the welfare effects of tying arrangements are ambiguous, they can be either efficient, neutral, or harmful, and this holds true even if the seller has market power, a general ban on tying (i.e., a per se rule against it) is not a wise policy unless one believes that the harms from tying arrangements plus adjudication and error costs make a per se rule more efficient. When the tying product is patented or copyrighted, the flaws of the per se rule become even more apparent because if sellers of intellectual goods are presumed to possess market power then any tying arrangement in the sale of their goods becomes per se illegal,

306. See HovenKAMP, supra note 17, § 10.1. Hovenkamp, following Yentsch v. Texaco, Inc., 630 F.2d 46, 56-57 (2d Cir. 1980), provides the following five-part test:

1) separate tying and tied products;

2) evidence of actual coercion by the seller that forced the buyer to accept the tied product;

3) a seller possessing sufficient economic power in the tying product market to coerce the acceptance of the tied product;

4) anticompetitive effect in the tied market; and

5) some interstate commerce in the tied product market.

HovenKAMP, supra note $17, \S 10.1$. According to Hovenkamp, all circuits are close to unanimous in requiring elements 1,3 , and 5. Id.

307. Hovenkamp, supra note 17, §10.1.

308. See, e.g., Arizona v. Maricopa County Med. Soc'y, 457 U.S. 332, 361-62 (1982).

309. See, e.g., Edward M. Iacobucci, Tying as Quality Control: A Legal and Economic Analysis, 32 J. Legal StUD. 435, 436-37 (2003).

310. United States v. Loew's, Inc., 371 U.S. 38, 45 (1962) (citations omitted), abrogated by ITW, 547 U.S. at 31.

311. HovenKAMP, supra note 17 , at $\S \S 10.6,10.7$; see also William F. Baxter \& Daniel P. Kessler, The Law and Economics of Tying Arrangements: Lessons from the Competition Policy Treatment of Intellectual Property, in COMPETITION POLICY AND Intellectual Property Rights In THE KnOWLEdGe-BASEd ECONOMY, supra note 68, at $137-38$. 
or at least potentially so, regardless of its actual effect on competition. Indeed, this would be the case even if in fact it is pro-competitive. Take ITW for example. The record before the Court contained no details about the effect of the tie. It could be that the tie effectively foreclosed the market for ink, and that monopolizing the market for ink would prevent competing printhead manufacturers from entering the market, thus raising the prices and reducing consumer welfare and the use of the patented technology, ${ }^{312}$ but there was no evidence of that yet. On the other hand, more likely the tie might allow Trident to maximize its profits by lowering the price of printheads and charging a supra-competitive price on ink, thus potentially increasing the use of its patented technology and consumer welfare, but so far there was no clear evidence about that either. ${ }^{313}$ A sensible analysis of tying cases would seek to know what the likely effect of the tie is before outlawing it. Yet the combination of a per se rule against tying and a presumption of market power may lead to condemnation of too many pro-competitive tying arrangements. From this perspective, when the Supreme Court in ITW abolished the presumption, and thereby raised the bar facing plaintiffs, it moved in the right direction.

It follows that while the combination of the per se prohibition on tying by firms possessing market power with a presumption that IP holders possess such power has been undeniably unfortunate, the true culprit has been the per se rule against tying by sellers possessing market power, not the presumption itself. Indeed, the Court in $I T W$ recognized the problem with current tying law. It correctly acknowledged that "[o]ver the years . . . this Court's strong disapproval of tying arrangements has substantially diminished"314 and that its previous jurisprudence reflected the "Court's historical distrust of tying arrangements." 315 But instead of attacking the flaw of tying law head-on, the Court chose to mitigate it indirectly. Rather than announcing rule of reason treatment for tying arrangements, the Court chose to require plaintiffs to prove market power. While both methods, rule of reason and no presumption of market power, increase the burden plaintiffs face and allow more tying arrangements to go unchallenged, the Court's decision maintains the basic flaw in tying law. It focuses on measuring the defendant's market power, instead of on the competitive effect of the tie, and simultaneously preserves the notion that tying arrangements engaged by "a true

312. See Brief of Professors Barry Nalebuff, Ian Ayres, and Lawrence Sullivan as Amici Curiae in Support of Respondent at 12-22, ITW, 547 U.S. 28 (No. 04-1329), 2005 WL 2427646; Brief of Professor F.M. Scherer as Amicus Curiae in Support of Respondent, supra note 147 , at $15-17$.

313. Several commentators have suggested that Trident indeed used the tie in that manner to engage in price discrimination via metering, although they have disagreed on whether the practice benefits or harms consumers. Compare Joshua Wright, Missed Opportunities in Independent Ink, 2005-2006 CATO S. CT. REV. 333, 350 (2006) (arguing that this form of price discrimination usually benefits consumers), with Barry J. Nalebuff, Unfit to be Tied: An Analysis of Trident v. Independent Ink, in THE ANTITRUST Revolution: Economics, Competition, And Policy (John Kwoka \& Lawrence White, eds., 5th ed. forthcoming), available at http://ssrn.com/abstract=1004087 (arguing that the same practice generally harms consumers and therefore should remain illegal per se).

314. ITW, 547 U.S. at 35 .

315. Id. at 38 . 
monopoly" remain unlawful. ${ }^{316}$ But because IP holders may engage in procompetitive tying arrangements even though they are true monopolies (even if they aren't presumed to be ones), the solace given to them by the Court is rather limited. $^{317}$

\section{A Presumption May be Justified Under Alternative Theories of Harm}

The preceding discussion has focused on the rationality or irrationality of tying law from a perspective focusing on economic efficiency. But although many believe that economic efficiency should be the ultimate goal of antitrust, the question is unsettled. ${ }^{318}$ Because the question of whether to have a presumption of market power is ultimately a question of policy, it is worth exploring whether different views about the goals of antitrust yield different answers to this question. I do not intend to determine the ultimate goal of antitrust here, only to demonstrate how different theories of harm may lead to different results concerning the desirability of a presumption of market power.

One alternative perspective, advocated by Professor Lande, for example, suggests that consumer choice is the ultimate goal of antitrust. According to this view, "[t]he antitrust laws are intended to ensure that the marketplace remains competitive so that worthwhile options are produced and made available to consumers, and this range of options is not to be significantly impaired or distorted by anticompetitive practices." 319 Under this standard, tying can be illegal because when a firm with market power over a product sells it only when packaged with a second product, consumers' choices are directly reduced and distorted by the arrangement. ${ }^{320}$ It is true that generally the availability of choices for consumers is not inconsistent with efficiency, yet in some cases the most efficient arrangement may be one in which choice is limited. In those cases, the view on antitrust's ultimate goals would determine whether liability exists.

Whether or not consumer choice should be the ultimate goal of antitrust, the concern about it has deep roots in the case law and especially in the case law on tying of intellectual goods. ${ }^{321}$ In Loew's for example, the Court expressed two concerns about tying: the first was that tying "may force buyers into giving up the purchase of substitutes for the tied product," and the second was that tying arrangements "may destroy the free access of competing suppliers of the tied product to the consuming market." 322 While the first concern was about consumers' choice, the second was about foreclosure, that is, the potential exclusionary effect of the tie. The connection between those concerns and market

316. Id. at 43 .

317. For a similar view, see David S. Evans, Untying the Knot: The Case for Overruling Jefferson Parish 13 (July 2006), available at http://www.usdoj.gov/atr/public/ hearings/single_firm/comments/219224_a.pdf.

318. See, e.g., HovenKAMP, supra note 17, § 2.2(d).

319. Robert H. Lande, Consumer Choice as the Ultimate Goal of Antitrust, 62 U. PitT. L. Rev. 503, 503 (2001).

320. Id. at 508 n.23.

321. Id. at 510 .

322. United States v. Loew's, Inc., 371 U.S. 38, 45 (1962) (citations omitted), abrogated by Ill. Tool Works Inc. v. Indep. Ink, Inc. (ITW), 547 U.S. 28, 31 (2006). 
power was that, according to the Loew's Court, a seller with market power "by virtue of his position in the market for the tying product, has economic leverage sufficient to induce his customers to take the tied product along with the tying item." ${ }^{323}$ The second concern, foreclosure, is the one that a theory of liability focused on economic efficiency would often emphasize, and it is quite obvious that many tying arrangements could not have any significant exclusionary effect of this kind. The first concern, however-reduction in choices available to consumers - is much more probable in imperfectly competitive markets. ${ }^{324}$ Therefore, so long as the Court's theory of liability reflected concern about the elimination of choice as such, it is perfectly logical to rule that the requisite economic power for illegal tying is much lower than market dominance and may be inferred from the tying product's desirability to consumers or from uniqueness in its attributes. ${ }^{325}$

If I am correct in suggesting that the number of available substitutes in markets or IP goods is often smaller than perceived in the AGLIP world, then a court motivated by concern for consumers' choice is adopting a sensible policy when it presumes that IP rights confer enough power to reduce the choices available to their customers. In other words, the Loew's Court correctly understood the power that IP rights confer upon their owners and correctly concluded that this power may allow them to force their customers into arrangements that would reduce the latter's choices. Under such theory of harm, the presumption makes sense. The Court was wrong, however, when it concluded that this elimination of consumer choice presumptively forecloses the market for the tied product, because such a conclusion requires an additional assessment of the competitive conditions in the market for the tied product and a convincing theory about how the tie will harm competition.

In sum, as an instrument of legal policy, the presumption of market power in tying cases is a sensible policy if the ultimate underlying policy is the preservation of consumer choice. However, it does not make much sense if the ultimate underlying policy is total welfare maximization, as an IP holder's initial market power tells us very little about her ability to use the tie to create a privately beneficial but socially inefficient arrangement. But what has made the presumption particularly pernicious in tying cases is that underlying substantive law dictates that whenever a seller with market power ties other products or services the practice is illegal. While the ITW Court improved tying law by rejecting the presumption of market power, it missed the opportunity to relieve tying law of its fundamental flaw.

323. Id.

324. See, e.g., HovenKAMP, supra note 17, § 10.3(a) (“Anticompetitive tie-ins are implausible in perfectly competitive markets. Competition drives prices to marginal cost, and the forced purchase of an unwanted product will be treated by a purchaser as a price increase. Such an increase is possible only if the seller has some market power.").

325. Id. 


\section{A Presumption Could be Defensible Under a Rule of Reason Analysis for Tying}

The current per se rule against tying shifts the focus of the analysis from the competitive effect of the tying arrangement to the threshold question of market power. In contrast, if tying arrangements were subject to a complete rule of reason analysis, then a presumption that IP holders do possess market power, or at least a permissible inference thereof, could make sense. As explained earlier, if a practice has been shown to have an anticompetitive effect, then the defendant's existing market power should be relevant if the court seeks to weigh this anticompetitive effect against some pro-competitive outcomes of the practice. This is because the greater the existing market power, the greater the deadweight loss created from its increase, and therefore greater efficiencies are required to outweigh it. Applying a presumption of non-trivial market power at this stage of the proceeding would not endanger tying arrangements that are purely pro-competitive. It would not be necessary for tying arrangements that are purely anticompetitive. But it may help challenging those arrangements with mixed effects. Whether such help is desirable ultimately depends on one's preferences about the respective costs of error, but it cannot be utterly indefensible. There are at least three reasons this makes some sense. First, if the tie has some anticompetitive effect, it is evidence of at least some market power. ${ }^{326}$ Second, litigated IP rights typically do confer substantial market power. Third, as a matter of judicial efficiency, a presumption against the tying IP holders would compel them to furnish evidence about the pro-competitive effects of the tie, evidence which they are best positioned to supply and which is essential for a meaningful rule of reason analysis.

Considering the relationship between the presumption of market power and the substantive law of tying, and considering that most of the cases in which the presumption of market power was applied have been tying cases, it seems that the anti-presumption of market power should be understood as a crude response by lower courts and the U.S. antitrust agencies to the negative consequences of the per se rule against tying rather than representing a universal truth about the relationship between IP rights, market power and antitrust policy. Because under U.S. per se rules the presumption of market power almost dictates the legal outcome of a dispute regardless of its economic merit, rejecting the presumption seemed like a sound policy in this context. ${ }^{327}$ But unlike lower courts and the antitrust agencies, the Supreme Court could have departed from the per se rule. Unfortunately, instead of doing so, it chose to mitigate its consequences by adopting the "anti-presumption" of market power. While this makes sense in tying (as long as the per se rule persists), it can have negative consequences in other contexts, especially because the reasoning does attempt to represent a universal truth about the relationship between IP rights and market power. Extending the

326. Id. $\S 10.3$.

327. That the presumption of market power may be rebutted does not solve the problem. When sellers have market power, it is difficult to rebut that they do (unless the definition is fudged). This also implies that rejecting the presumption is only a partial solution, because market power can still be proved. In both cases, efficient ties will be outlawed. What needs to be rebutted is the presumed anticompetitive effect of the tie. 
anti-presumption to other contexts, which may involve other policy objectives and may be governed by different theories of harm and other procedural and evidentiary rules, may hinder, not facilitate, the correct result. I explore one such context in the next section.

\section{Enforcement of Invalid Intellectual Property Rights: Walker Process Litigation}

Unlike pre-ITW tying cases, in Walker Process, a case dealing with an attempt to enforce an invalid patent, the Supreme Court refused to infer market power (necessary for a monopolization claim in this case) from the mere existence of a patent. ${ }^{328}$ The Court noted, "[i]t may be that the [patented] device ... does not comprise a relevant market. There may be effective substitutes for the device which do not infringe the patent. This is a matter of proof . . ." 329 However, analyzing all factors, including questions of probability, policy objectives and the underlying theories of harm and procedural rules, reveals that Walker Process presents a case in which a presumption of market power, or at least a "permissive inference" ${ }^{\$ 30}$ could be desirable, or at least sensible.

The issue in Walker Process was whether an attempt to enforce a patent obtained by fraud amounts to an act of illegal monopolization under section 2 of the Sherman Act. Walker, the alleged infringer, and the United States, appearing as amicus curiae, argued that if Food Machinery \& Chemical ("FMC"), the patent holder, "obtained its patent by fraud and thereafter used the patent to exclude Walker from the market through 'threats of suit' and actual prosecution of this infringement suit, ... proof [of such conduct] would establish a prima facie [section 2] violation .... ${ }^{331}$ In response, FMC argued that a patent monopoly and a Sherman Act monopoly cannot be equated. ${ }^{332}$ The Supreme Court, while accepting that an enforcement of a patent fraudulently obtained may amount to a violation of the Sherman Act, held that the other elements necessary in a monopolization case must be present in order to establish liability. ${ }^{333}$ The Court held that in order to establish the section 2 claim "it would . . . be necessary to appraise the exclusionary power of the illegal patent claim in terms of the relevant market for the product involved. Without a definition of that market there is no way to measure Food Machinery's ability to lessen or destroy competition." ${ }^{\text {334 }}$ The Court hypothesized that the device in question might not comprise a relevant market, that there might be effective substitute devices that did not infringe that patent, and concluded that this was a matter of proof by Walker. ${ }^{335}$

The Court correctly held that the ability of FMC to monopolize the market was ultimately a matter of proof by Walker. The question, however, is what

328. Walker Process Equip., Inc. v. Food Mach. \& Chem. Corp., 382 U.S. 172, 174, 177-78 (1965).

329. Id. at $177-78$

330. See supra Part VI (classification of presumptions).

331. Walker Process, 382 U.S. at 175.

332. Id.

333. Id. at 177 .

334. Id.

335. Id. at $177-78$. 
evidence Walker had to furnish in order to meet this burden and whether a court could infer that FMC had the requisite market power from the facts that were proven. Further at issue is whether as a matter of policy the court should have inferred that FMC had the requisite market power. I argue that it could have and that some policy considerations suggest that it should have.

Admittedly, the position of Walker and the United States was probably too simplistic, and the Court correctly refused to adopt it. The mere fact that FMC attempted to enforce a patent does not tell us much about the effect of that act on the competition in the market which is allegedly monopolized. However, it is an additional fact - that the patent is attempted to be enforced against a competitorwhich tells us a lot about the effect of such an attempt in the market in which they both compete, even without precisely defining what this market is. If both parties are engaged, actually or potentially, in the same economic activity within the same geographic market, in other words if they are competitors, then it is not unreasonable for a court to infer from an attempt by one competitor to exclude the other that it faces an attempt to create, strengthen, or maintain market power. As noted, if the market is highly competitive, the plaintiff will gain very little from the exclusion of a competitor because the output reduction (and price increase) that will result from the exclusion of that infringing defendant will be rapidly offset by output expansion by non-infringing competitors. ${ }^{336}$ The fact of exclusion (or its attempt) defines the market. ${ }^{337}$ Requiring a full-blown trial just to define the market in such circumstances is not only a waste of resources but can also increase the risk of error. ${ }^{338}$ Assuming the enforcement of invalid IP rights is a behavior that should be discouraged, a rebuttable presumption, or at least a permissive inference that the plaintiff has sufficient market power necessary for a monopolization claim in such circumstances, can promote this goal. ${ }^{339}$ Oddly, the Court refused to do so.

336. See supra Part III.D.

337. Judge Bork made a similar argument to support the per se prohibition on naked price-fixing or market-division agreements. He noted that "[v]ery few firms that lack power to affect market prices will be sufficiently foolish to enter into conspiracies to fix prices. Thus, the fact of agreement defines the market." ROBERT H. BORK, THE ANTITRUST PARADOX: A Policy AT WAR With ITSELF 269 (1993).

338. Id.

339. HovENKAMP ET AL., supra note $66, \S 11.4(\mathrm{c})$. Although arguing that a plaintiff in Walker Process claims must demonstrate that the IP owner has market power, Hovenkamp et al. make a similar argument with regard to the anticompetitiveness of the act. Id. $\S 11.4(\mathrm{~b})$. They argue that "antitrust claimants who can demonstrate that a monopolist has engaged in sham litigation against competitors should be able to demonstrate anticompetitive conduct as a matter of course." Id. § 11.4(c) (emphasis added). However, if it is possible to prove an anticompetitive effect, an inquiry into the question of market power is superfluous.

Since the purpose of the inquiries into market definition and market power is to determine whether an arrangement has the potential for genuine adverse effects on competition, "proof of actual detrimental effects, such as a reduction of output," can obviate the need for an inquiry into market power, which is but a "surrogate for detrimental effects." 
Indeed, the history of the disputes between FMC and Walker supports my proposition. FMC and Walker fiercely competed in the area of sewage treatment systems and had a long history of patent litigation. The facts of an earlier case involving FMC demonstrate that both firms used technology that presented substantial improvement over prior technologies. ${ }^{340}$ That technology reduced the treatment time from thirty days to ten days, thus allowing municipalities to better utilize their existing treatment facilities and avoid building new facilities. ${ }^{341}$ FMC had some patents on several aspects of the technology. The patents would not necessarily be infringed by Walker's equipment and in at least one case Walker's process was found to be non-infringing. ${ }^{342}$ Nevertheless, the fact that Walker's equipment could be used in an allegedly infringing manner was used by FMC to raise Walker's costs. FMC tried to persuade prospective customers of its competitors to use its equipment in accordance with its patented technology, and encouraged them, if they chose the equipment of competitors, to purchase a license from FMC in order to avoid possible infringement. ${ }^{343}$ As a result, Walker often had to furnish "hold harmless" guarantees to defend its customers from infringement actions brought by FMC. ${ }^{344}$ In at least one case mentioned above, FMC sued a customer of Walker and Walker had to handle the defense. ${ }^{345}$ Walker attempted to bar subsequent cases by seeking a declaratory judgment to determine the scope and validity of the patent but failed on the grounds that there were no outstanding charges against Walker or its customers. ${ }^{346}$ While this recurring litigation does not present a full picture of the competitive landscape of the sewage treatment market, it does suggest that there were substantial rents to fight over in that market, a finding that is more consistent with the existence of market power than with its absence.

While these facts suggest that a presumption of market power in such cases is justified on grounds of probability and procedural efficiency, there are additional supporting policy considerations. As Judge Bork noted in 1978, the harms to competition caused by sham litigation may be significant and create a special challenge for antitrust because such litigation, often pursued before other agencies, often has low antitrust visibility. ${ }^{347}$ Professor Meurer has recently noted that predatory litigation seems more likely than classic predatory pricing strategies and suggested that the problem of opportunistic IP litigation is serious and is getting worse. ${ }^{348}$ The Federal Trade Commission, following a series of public hearings held in 2002, has expressed concerns that too many issued patents are of

FTC v. Indep. Fed'n of Dentists, 476 U.S. 447, 460-61 (1986) (quoting 7 PHILlIP AreedA, ANTITRUST LAW 429 (1986)).

340. FMC Corp. v. City of Greensboro, 326 F.2d 581, 582-83 (4th Cir. 1964).

341. FMC Corp. v. City of Greensboro, 208 F.Supp. 494, 495 (M.D.N.C. 1962). In that case, the technology would save the City of Greensboro $\$ 210,000$. Id.

342. FMC Corp., 326 F.2d at 584-85.

343. Walker Process Equip., Inc. v. FMC Corp., 356 F.2d 449, 450 (7th Cir. 1966).

344. Id.

345. FMC Corp., 326 F.2d at 583.

346. Walker Process, 356 F.2d at 451.

347. BORK, supra note 337, at 347-49.

348. Meurer, supra note 148, at 516. 
questionable validity, and when combined with some existing legal standards and procedures, these patents may actually have anticompetitive effects. ${ }^{349}$ The Federal Trade Commission also made some recommendations to improve patent quality and minimize the anticompetitive costs of the patent system. ${ }^{350}$

However, despite those concerns and the ruling in Walker Process that an attempt to enforce a patent obtained by fraud may amount to an act of illegal monopolization, Walker Process claims are usually not successful. ${ }^{351}$ A high degree of caution in accepting such claims is indisputably warranted, and there should be no intention to chill the enforcement of valid IP rights. Therefore, in order to prevail, a Walker Process claimant must prove that the patentee intentionally deceived the Patent and Trademark Office and that the patent would not have been granted but for the patentee's fraud. ${ }^{352}$ Furthermore, "good faith or an honest mistake "would furnish a complete defense.",353 This standard effectively bars many claims because the information asymmetry with regard to the facts necessary to prove those elements favors the patentee. ${ }^{354}$ Additionally, the patentee also benefits from a statutory presumption of validity. ${ }^{355}$ This presumption is particularly strong, even stronger than an ordinary MorganMcCormick presumption discussed earlier, ${ }^{356}$ because the Federal Circuit has ruled that the presumption can only be rebutted by the heightened "clear and convincing evidence" standard. ${ }^{357}$ All of these may be sufficient to filter out many Walker Process claims. Adding an additional requirement to define the market and prove market power creates an additional burden on potential claimants that may simply be too high. Therefore, allowing courts to presume that such sham litigation is aimed at increasing the market power of the patentee can help extend the limited reach of antitrust to this type of anticompetitive behavior. ${ }^{358}$

\section{Avoiding Oversized Antitrust LaW}

One of the main points of this Article is that an IP right often confers upon its owner the ability to set price substantially above marginal cost and that this ability is market power in the antitrust sense. Yet, I have also argued that for

349. Fed. Trade Comm'n, To Promote Innovation: The Proper Balance of COMPETition ANd PATENT LAw AND Policy 5 (2003), available at http://www.ftc.gov/ os/2003/10/innovationrpt.pdf.

350. See id. at 7-18.

351. HOVENKAMP ET AL., supra note $66, \S 11.2(\mathrm{f})$.

352. Id. $\S 11.2(\mathrm{c}),(\mathrm{d})$.

353. Id. § 11.2(c) (quoting Walker Process Equip., Inc. v. Food Mach. \& Chem. Corp., 382 U.S. 172, 177-178 (1965)).

354. See Meurer, supra note 148, at 514.

355. 35 U.S.C. $\$ 282(2006)$.

356. See supra Part VI.

357. Am. Hoist \& Derrick Co. v. Sowa \& Sons, Inc., 725 F.2d 1350, 1360 (Fed. Cir. 1984); see also FED. TRADE COMM'N, supra note 349, at 26-28 (recommending that legislation be enacted specifying that challenges to the validity of a patent be determined based on the general standard of "preponderance of the evidence").

358. See Meurer, supra note 148, at 539 ("Trebled antitrust damages are a potent deterrent of anticompetitive activity, but in practice antitrust does little to control socially harmful IP litigation because its reach is very limited."). 
antitrust purposes the fact of market power should be distinguished from the question of whether a specific practice or conduct increases or maintains that market power. I explained that for most antitrust purposes only the last question matters and that the degree of market power that existed prior to the challenged conduct matters only if this conduct increases or maintains that market power and creates an additional, much larger, deadweight loss as a result. On the basis of this framework, I have identified some cases in which a rebuttable presumption that IP rights confer market power may make sense.

One implication of this view, potentially contentious, is that this analysis may result in greater risk of antitrust liability for many owners of IP rights because it could apply to sellers of intellectual goods that would generally be considered non-dominant under traditional methodology of antitrust analysis.

Consider the following example: suppose there are two software publishers, $A$ and $B$, who sell differentiated but functionally similar products (e.g., word processors such as Word and WordPerfect). The two publishers independently enter into exclusive dealing arrangements downstream and these arrangements undergo some antitrust scrutiny. Traditional antitrust analysis would begin with defining the market, which may be defined as "word processing software for Intel compatible personal computers." Assume that under this definition of the market $A$ has a market share of $90 \%$ and $B$ 's market share is $10 \%$. Ordinarily, the inquiry with regard to $B$, being non-dominant, will end at this point because there is a strong presumption that a competitor whose market share is $10 \%$ cannot profitably behave anticompetitively. ${ }^{359}$ However, suppose that as a result of the arrangements the prices of both firms' products increase by $10 \%$. Recall that both products are differentiated so it is not improbable that each of them could employ some strategies that, within limits, enable prices to be raised profitably. Continue to assume, as in Example 2 discussed above, that there are 100 consumers, that marginal cost is $\$ 10$, the initial price was $\$ 100$ and that 10 of them ( 9 for $A$ and 1 for $B$ ) are discouraged from buying if the price increases by $10 \%$. Further assume that no offsetting efficiency gains can be demonstrated. The total loss from $A$ 's arrangement is $\$ 855$ and the total loss from $B$ 's arrangement is $\$ 95$. $^{360}$ The loss from $B$ 's arrangement is still significant. Indeed, it is 19 times higher than under the competitive assumption of Example 1 discussed earlier. ${ }^{361}$

This example reveals that although "word processing software for Intel compatible personal computers" sounds like a plausible definition of the market, given that the two firms sell this type of software and compete with each other, this definition is largely irrelevant for assessing the effect of the challenged conduct. ${ }^{362}$

359. The AGLIP, for example, define a "safety zone" of twenty percent or below of any of the markets affected by the restraint. AGLIP, supra note $6, \S 4.3$.

360. See supra Part V.B. Recall that the discouraged consumers are those that were willing to pay above $\$ 100$ but not $\$ 110$ and the total surplus associated with each of them is the difference between each's willingness to pay and marginal cost, which is on average $\$ 95$. The total loss from $A$ 's conduct is $\$ 855=9$ X 95 and $\$ 95$ from $B$ 's.

361. See supra Part V.B. The total loss in Example 1, which resulted from a tenpercent increase in prices in a previously highly competitive market, was only $\$ 5$.

362. It does not mean that this definition cannot be appropriate in other scenarios. If, for example, it was alleged that $A$ and $B$ colluded to enter into exclusive arrangements 
If the challenged conduct was found to allow $B$ to raise its prices, then under this proposed framework $B$ 's software was a relevant market for assessing the effect of its exclusive dealership arrangement.

Few would challenge the proposition that if we actually have enough evidence demonstrating that such price increase is possible, $B$ 's software should indeed be considered the relevant market. Yet many could argue that the broader market definition is nonetheless justified because ordinarily we do not have such evidence. In such cases the exercise of defining the relevant market enables us to determine the likelihood of such price increase by $B$. Finding, under the broader market definition, that $B$ is unlikely to be able to raise its price serves as a screening device that saves the cost of antitrust litigation against $B$. Such saving is justified if the cost of error, that is, the cost of letting $B$ get away under the broader market definition, is not high. Note, however, that the magnitude of the cost of error depends on the amount of $B$ 's existing market power. If $B$ has no existing market power (as in Example 1), the cost of letting it get away is $\$ 5$, whereas if $B$ does have market power (as in Example 2) the cost of error in letting it get away is $\$ 95$. If we assume that $B$ does possess market power, the methodology of initially defining the market without giving weight to the existence of IP rights may be a screening device that screens too much.

Does it mean that $B$ should be considered a monopolist for antitrust purposes and found liable in such circumstances? Some may worry that a positive answer would imply very interventionist antitrust law, perhaps overly interventionist. But if we think that the answer should be negative, what would the basis for that be? What is the basis for not applying the antitrust laws against a practice that without compensating efficiency gains was proven to have raised prices, thereby creating deadweight losses? Is there a more compelling answer than saying that $B$ has market power but "not in an antitrust sense"?

One important consideration that prevents such wide application of antitrust laws against owners of IP is the magnitude of the actual effect of the challenged conduct on the economy - the actual size of the injury caused by the conduct. In this last example, if the numbers were real ones and the size of $B$ 's consumer base actually reduced from ten consumers to one and the resulting deadweight loss was merely $\$ 95$, it is obvious that an antitrust proceeding may not be cost justified. ${ }^{363}$ IP holders whose markets are very small may thus be effectively shielded from antitrust liability not because they would be legally immune, but because there will be only few potential plaintiffs, who in any event will be deterred by the costs of litigation. Time may equally determine the size of economic activity affected by the practice. The deadweight loss associated with an increase in the price of an intellectual good can be small even if the market is large (in terms of the number of consumers multiplied by the prices that they pay) when the commercial lifespan of the work is very short. Today's copyrighted newspaper article, which may be highly valuable today but of no value tomorrow, is an

with their dealers in order to divide the market between them and prevent entry from third parties, or the challenged conduct was a proposed merger between them, the definition could be appropriate.

363. Landes \& Posner, supra note 88, at 953-54. 
obvious example. ${ }^{364}$ While it may not be practical, or even desirable, ${ }^{365}$ to define a threshold of economic activity that would trigger antitrust scrutiny, the fact that pursuing antitrust actions against IP holders is costly creates de facto an important filter against the danger of oversized antitrust law. ${ }^{366} B$ and its fellow IP holders can rest assured that they are unlikely to be antitrust defendants.

Another consideration that minimizes the danger of oversized antitrust scrutiny of IP owners' conduct is that I assumed that $B$ could profitably raise its prices and that the resulting deadweight loss was larger than any potential efficiency gains. In practice, a plaintiff would have to prove that this is the case, which may be a crucial difference. A court may justifiably wonder why the price increase is not constrained by the availability of the other software. But the constraining impact is not symmetric. $B$ is more likely to be constrained by $A$ than $A$ by $B$ (for example, because $A$ 's larger user base may indicate easier access to consumers). Consequently, a court may be more receptive to finding the allegation raised against $A$ probable and rule against $A$, and more reluctant to rule against $B$. It does not mean that $B$ will always be constrained by $A$, only that proving that this is not the case is more difficult.

But such institutional and practical considerations are not the only considerations against antitrust imperialism. The preceding analysis was essentially static; it focused on assessing the efficiency gains (or lack thereof) created by the challenged conduct. But because we are dealing with IP, dynamic considerations, primarily the effect on the incentive to innovate, are no less important. It could be argued that the challenged practice of the IP holder should nevertheless be endorsed even if it does not create identifiable net efficiency gains simply because the additional profit to the seller would eventually pay off in the form of greater incentives to innovate and a resulting increase in productivity, despite the static short-term deadweight loss. In other words, condemning the practice would reduce the incentives to innovate and result in long-run losses greater than the immediate loss associated with the practice. The focus here is not on the expected efficiency gains from the practice itself (we assume that no such net short-term gains exist) but with the effect that allowing or prohibiting the practice would have on the profits of the IP holder and thereby on the expected reward from innovation generally. In this respect, allowing the IP holder to impose restrictions that create no static efficiency gains and whose only effect is to increase the IP holder's profits can be simply seen as part of the initial reward of the IP right, and the remedy for such short-term losses will be found in the selfcorrecting mechanism of further innovation with its associated benefits. This approach would essentially favor antitrust immunity for many IP-related practices.

364. This same article, however, may regain value over time as a record of historic events, which researchers or other creators might value. This may explain why many newspapers allow free online access to their internet editions for the last seven or thirty days, but require payment for access to older materials.

365. Landes \& Posner, supra note 88, at 953 (suggesting that the existence of deterrent benefits can occasionally justify bringing a suit against small monopolists).

366. The same applies to IP law. The fact that consumers can often use intellectual goods in an infringing manner without being sued, because enforcing the IP is not cost-justified, creates a practical check to overreaching IP law. 
Although attractive for IP holders, this approach is certainly incompatible with the AGLIP, which denounce any such special immunity and maintain that "certain types of conduct with respect to intellectual property may have anticompetitive effects against which the antitrust laws can and do protect." ${ }^{367}$ Furthermore, such an approach is hardly tenable as a matter of principle. One can easily conceive of instances in which the magnitude of short-term losses will be large and the benefit of marginal increases in future innovation will be limited. It is also imaginable that anticompetitive practices carried out today might impede the innovative process itself.

Moreover, concern about the effect of potential antitrust liability on the incentives to innovate, although important, should be taken with a grain of salt. As noted previously, the effect of the last increment of monopoly pricing on the IP holder's profits (and incentives to innovate) is relatively small compared to the large deadweight losses created by exercising that power. ${ }^{368}$ In addition, the effect of restrictions on the exercise of IP rights on the incentive to innovate may differ across industries because the importance of IP in inducing investment in R\&D is not the same in all industries. ${ }^{369}$ Thus, more caution may be justified in some industries than in others.

\section{CONCLUSION}

IP rights are designed precisely to create artificial scarcity of intellectual goods. They are meant to allow their owner to set their prices in excess of marginal cost, to exercise market power. Therefore, it should not be surprising that on many occasions this is exactly what they do. It is even more likely that disputes evolve around those IP rights that do confer market power. Consequently, on grounds of probability and as a factual matter, a rebuttable presumption that IP rights confer market power upon their owners can be justified.

Nevertheless, a "virtual consensus" has emerged, criticizing courts' willingness to presume these simple truths, culminating in ITW with the rejection of the presumption by the Supreme Court. I have shown, however, that much of this criticism has resulted from attempts to analyze the relationship between IP rights and market power in the abstract rather than in connection to a specific practice or conduct and from a failure to distinguish between the empirical justification for the presumption and its desirability as a matter of judicial policy. I have also shown that in tying cases, where the presumption was most frequently and justifiably attacked, the true culprit has been the per se rule against tying, not the presumption itself. Unfortunately, the Court in ITW missed the opportunity to deal with the true culprit.

In this Article, I present a different approach to understanding the relationship between IP rights, market power, antitrust, and the question of the presumption of market power. I show that for most antitrust purposes, the fact that a firm has market power is irrelevant because the focal point of most antitrust

367. AGLIP, supra note $6, \S 2.1$.

368. Ayres \& Klemperer, supra note 103, at 990.

369. See, e.g., Michael A. Carrier, Unraveling the Patent-Antitrust Paradox, 150 U. PA. L. REV. 761, 823-26 (2002). 
questions is the change in market power resulting from a specific practice or conduct. Existing market power can nonetheless be relevant, but only if the conduct is found to be anticompetitive. It is relevant for measuring the magnitude of the harm caused by the anticompetitive outcome of the conduct and then balancing this harm against potential efficiency gains. Using this approach, the concept of market power in antitrust can be understood in its ordinary textbook meaning: the ability of a firm to set prices substantially above marginal cost and sustain them. Acknowledging that and focusing on the change in market power would not lead to an oversized application of antitrust to IP-related conduct.

Given this traditional definition of market power and this analytical framework, I have identified some examples of cases and typical questions in which a presumption of market power can be justified on policy grounds. I have not considered the type of presumption it should be: whether courts should adopt a Thayer-Wigmore presumption, Morgan-McCormick presumption, or whether a rule of permissive inference would suffice. As I have noted, the answer is highly context specific and depends on various factors. The answer may change depending on the underlying substantive antitrust rules (e.g., whether a finding of market power compels a finding of liability or not), on other rules relating to the legal process (e.g., standing requirements, standards of proof, available remedies), on the combined effect of those substantive and procedural rules, and on the expected effect of a presumption of market power on the likelihoods of plaintiffs to prevail. The existence and strength of the presumption may also depend on one's approach to the cost of error: whether we should err on the side of more active antitrust or stronger IP rights. Moreover, avoiding exact delineation of the nature and strength of the presumption may in fact be desirable because the existence of a presumption of market power dialectically undermines its empirical basis (and the lack of such presumption dialectically strengthens the empirical grounds for having one). Consequently, the overall merit of the presumption-the balance of all of those considerations - may vary over time in a pendulum movement.

The purpose of IP law is to "promote the Progress of Science and useful Arts. ${ }^{370}$ The results are intellectual goods: innovative products, services, and creative works. By definition, when this result is achieved and such innovative intellectual goods are created they do not have very close substitutes, and if such goods are valuable for consumers their owners can exercise market power. Both IP law and antitrust play important role in restraining this market power in an uneasy attempt to find and maintain the right balance between providing enough market power as incentive to innovate and minimizing its social cost. Much of the modern analysis of IP and antitrust is based on an "anti-presumption" of market power; an assumption that most intellectual goods have close substitutes that prevent the exercise of market power, and on a futile attempt to distinguish between simple (and benign) market power and (malignant) market power in the antitrust sense. This is unrealistic and unnecessary. Striving to focus on the precise anticompetitive effect of a challenged practice may help us find the proper role for antitrust without resorting to unrealistic assumptions. Surely, this is not going to be 
easy. However, this task will not be made any easier by assuming that there generally are many close substitutes when often there are few or none; asserting that IP rights are comparable to other forms of property when important and relevant differences exist; and consequently pretending that market power does not generally exist when it often does. 